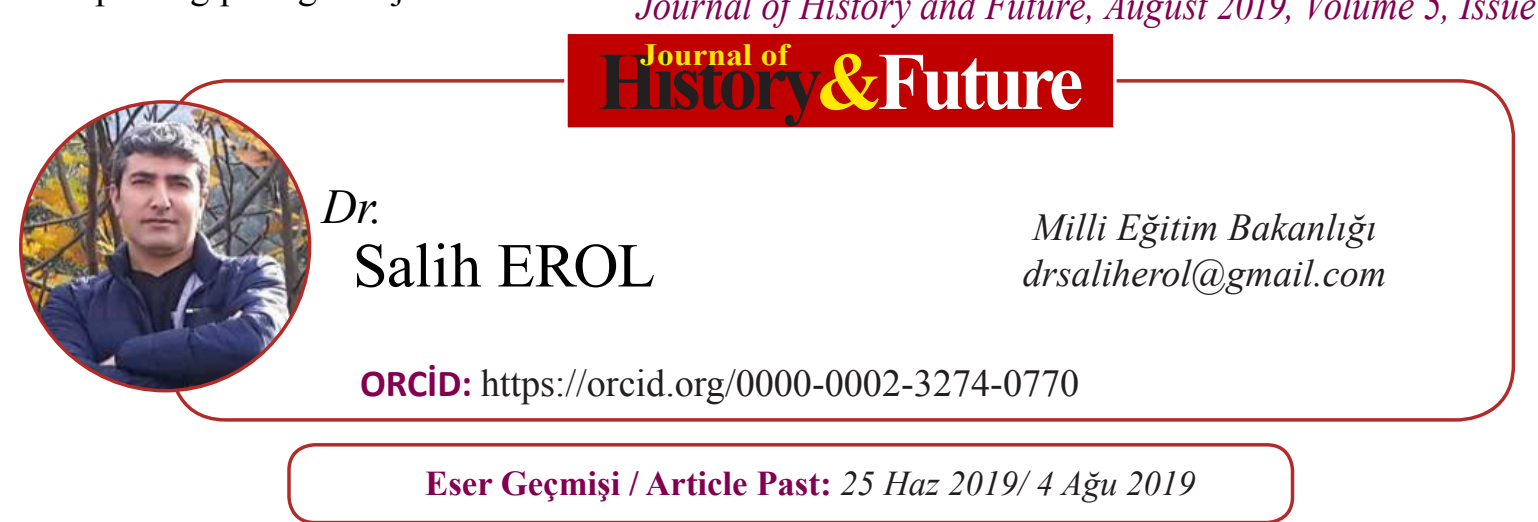

Araştırma Makalesi DOI: http://dx.doi.org/10.21551/jhf.581837 Research Paper

Orjinal Makale / Orginal Paper

\title{
Türk Basın Tarihinde İbrahim Şinasi Efendi ve Tasvir-i Efkâr Gazetesi
}

\author{
İbrahim Şinasi Efendi and Tasvir-i Efkâr in The History of Turkish \\ Press
}

\section{$\ddot{O} \mathbf{z}$}

İstanbul'da Türkçe basım yapan matbaanın ilk kitabı basmasından yaklaşık yüzyıl sonra Türkçe gazetelerin ilk örneği yayınlandı. 1831'de devletin resmi yayın organı olarak Takvim-i Vekayi Gazetesi çıarıldı. Bunun üzerinden yaklaşık otuz yıl geçtikten sonra bu kez ilk Türkçe özel gazeteler çıkmaya başladı.

Türk basın tarihinde "Türkçe özel gazeteler devri”nin başlamasında en etkili olan şahsiyetlerin başında İbrahim Şinasi Efendi gelmektedir. Tipik Tanzimat aydınlarının öncülerinden olan Şinasi, Batı'yı yerinde tanımaya çalışmış ve Osmanlı Toplumu'nun Batılılaşmasını savunmuştur. Çok yönlü bir aydın olan Şinasi, gazeteler aracılığıyla halkın aydınlatılabileceğine; kamuoyu oluşturulabileceğine inanmış biri olarak Tercüman-1 Ahval'in yayınını başyazar olarak bir dönem yönettikten sonra kendi matbaasını ve gazetesini kurmaya çalışmıştır.

Şinasi'nin yoğun çalı̧şmasının sonucu olarak 1862'de yayın hayatına başlayan Tasvir-i Efkâr Gazetesi, Türkçe basında önemli bir yere sahiptir. Haber gazeteciliğinin yanı sıra bir fikir gazetesi olarak da dikkat çeken bu gazete, daha sonra kendi gazetelerini çıkaracak olan birçok Türk genci için bir okul işlevi görmüştür. Tasvir-i Efkâr, bütün zorluklara rağmen yaklaşık yedi yıl boyunca yayınını sürdürmüş̧tür.

Anahtar Kelimeler: Şinasi, Tasvir-i Efkâr, Matbaa, Gazete, Tanzimat.

ATIF: EROL Salih, "Türk Basın Tarihinde İbrahim Şinasi Efendi ve Tasvir-i Efkâr Gazetesi”"

Tarih ve Gelecek Dergisi, 5/2 (Ağustos-2019), s. (273-295)

CITE: EROL Salih, "İbrahim Şinasi Efendi and Tasvir-i Efkâr in The History of Turkish Press"

Journal of History and Future, 5/2 (August- 2019), pp. (273-295) 


\begin{abstract}
Abtract
About a century later the first Turkish printing book, the first Turkish newspaper published in İstanbul. Takvim-i Vekayi published in 1831 as an official periodical publication of the Ottoman State. About thirty years later, this time the first non - official Turkish newspapers began to publish.

İn the beginning “Turkish non-oficcial newspapers age” İbrahim Şinasi Efendi was the top of the most effective persons. He was a typical Tanzimat intellectual whom tried to recognize the West and defended the Westernization of the Ottoman Society. Şinasi, as a sophisticated intellectual, believed that people can be illuminated by newspapers. He tried to establish his own printing press and started a newspaper of his own after he had administered the Tercüman-1 Ahval publication as editor.

As a result of Şinasi's intensive working Tasvir-i Efkâr which started publishing in 1862 has an important place in The Turkish press. İt has been atracted attention a news journal as well as a comment journal and for many Turkish young people Tasvir-i Efkâr has a school function. Despite all the difficulties Tasvir-i Efkâr went on its publishing for seven years.
\end{abstract}

Keywsords: Şinasi, Tasvir-i Efkâr, Printing Press, Newspaper, Tanzimat.

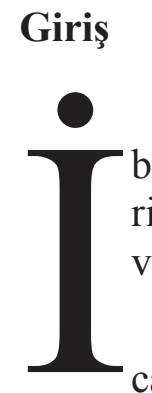

brahim Şinasi Efendi’nin ve sahibi olduğu Tasvir-i Efkâr Gazetesi’nin Türk basın tarihindeki yerlerinin daha iyi anlaşılması için giriş bölümünde Osmanlı' da matbaacılık ve ilk gazetecilik faaliyetlerini özetlemek gerekmektedir.

XV. Yüzyılın ortalarına doğru, Almanya'da Johann Gutenberg tarafında icat edilen modern matbaa insanlık tarihinin en önemli kültürel olaylarından biridir. Kültürel devrim niteliğindeki bu matbaa tekniği sayesinde önce kitaplar; ardından gazete ve mecmualar basılmıştır.

Osmanlı İmparatorluğuna matbaanın girişi, XV. Yüzyılın sonlarına denk gelmektedir. Osmanlı ülkesinde yaşayan Gayr-i Müslimler, bu konuda öncü rol oynamışlardır. Özellikle Yahudiler, II. Bayezıd zamanında (1481-1512) matbaa kurma ve kitap basma çalışmasını başlatmışlardır. İspanya'dan Osmanlı'ya sığınan iki Yahudi mülteci David ve Samuel, 1493'te İstanbul'da ilk matbaayı kurdular. Bunu 1530'da Selanik'te kurulan Yahudi matbaası izledi'. Ardından Halep, Edirne ve Şam gibi Osmanlı şehirlerinde de Yahudi matbaaları kuruldu. Yahudilerin ardından Ermeniler 1565 'te; Rumlar ise 1627 'de İstanbul'da birer matbaa kurdular. Azınlık matbaalarının dışında Avrupa devletlerinden bazılarının İstanbul'daki elçiliklerinin bünyesinde de matbaalar faaliyet göstermiştir. Öyle ki XVIII. Yüzyılın başlarına gelindiğinde, diğer bir deyişle ilk Türk Matbaası kurulduğunda, Osmanlı toprakları üzerinde otuz yedi matbaa faaliyet göstermekte idi².

Osmanlı Devletinde, ilk Müslüman- Türk matbaasının kurulması, oldukça geç sayılabile-

1 Stanford Jay Shaw, Osmanlı Imparatorluğunda ve Türkiye Cumhuriyetinde Yahudiler, çev. Meriç Sobutay, Kap1 Yay., İstanbul, 2008, s.167.

2 Jale Baysal, Kitap ve Kütüphane Tarihine Giriş, İstanbul, 1992, s. 70. 
cek bir tarihte, devlet eliyle ve devletin katı kurallarına tabi olarak, 1727 yılında kurulmuştur. Bu gecikmenin bir takım nedenleri olsa da çalışmamızın ana konusunu teşkil etmediği için, detayına girilmemiştir. III. Ahmet Döneminde (1718-1730) Paris'e elçilikle 1720 yılında Yirmisekiz Çelebi Mehmet Efendi gönderildi. Onunla birlikte Paris'e giden oğlu Sait Efendi ise, burada gördüğü teknik gelişmeler içinde matbaacılıkla özel olarak ilgilendi ve 1724'te İstanbul'a dönüşünde bir Türk matbaası kurmak için çalışmalara başladı.

Aslen Macar olan ve gençliğinde Osmanlılara esir düştükten sonra Müslümanlığ seçen İbrahim Müteferrika (1674-1747), oldukça iyi eğitim görmüş, zeki ve çalışkan bir kişidir. Bu sayede başta Nevşehirli Damat İbrahim Paşa olmak üzere, devlet adamlarının sempatisini kazandı ve devlet görevine girdi. Aynı zamanda matbaa tekniğini bilen Müteferrika, daha 1719'da sadrazama şimşir üzerine bastığı bir Marmara Denizi haritası hediye etmiş ve basım tekniğindeki yeteneğini göstermişti ${ }^{3}$.

İstanbul'da matbaa kurmak için faaliyetlere başlayan Sait Efendi, bu konuda bilgi sahibi olan İbrahim Müteferrika ile ortak hareket etti. Bu işbirliği sonucunda üst düzey ilmiye mensuplarından da destek aldılar. Şeyhülislam Abdullah Efendi, matbaanın kurulmasında dini bir sakınca bulunmadığına dair bir fetva verdi. Bu fetvanın ardından matbaaya izin veren hatt-ı hümâyûnla ilk Türk matbaası kurulmuş oldu. Böylece çalışmalarına 1727 yılı sonlarına doğru başlayabilen matbaa, ilk eserin basımını 31 Ocak 1729 yılında gerçekleştirdi.

\section{Osmanlı Devletinde Gazetelerin Gelişimi ve İlk Gazeteler}

Osmanlı Devletinde Türk Matbaasının kurulması ile Türkçe Gazetenin ortaya çıkması arasında birçok bakımdan benzerlikler vardır. İkisinde de dünyadaki benzerlerine nazaran çok geç kalınmıştır. Örneğin, Avrupa'da ilk gazete örnekleri XVII. Yüzyıldan itibaren çıkarken, Osmanlı'da ancak XIX. Yüzyılda ilk Türkçe gazete örnekleri çıkmıştır. Matbaacılıkta olduğu gibi gazetelerde de önce Osmanlı'da yaşayan azınlıklar ve yabancılar başlamış; ancak daha sonra Türkler bu işe başlayabilmişlerdir.

Başkent İstanbul'da bilinen ilk gazete Fransız elçiliği matbaasında, 1795'te Fransızca yayınlanan Bulletin Des Nouvelles adlı haber bültenidir. Fransız Devriminin ilkelerini, felsefesini anlatmak, "Cumhuriyetin yeni kanunlarının Şark'taki mümmesileri tarafından daha iyi öğrenilmesi” amacıyla çıkarılan bu gazeteden bir yıl sonra aynı amaca sahip ikinci bir gazete Gazette Francaise de Constantinople adlı bir gazete daha Fransız elçiliği tarafından çıkarıldı. Osmanlı memleketinde çıkan bu ilk iki örnek, tam anlamıyla birer gazete sayılamaz. Toplum katmanlarında yaygınlık kazanamamış, düzgün bir periyodik özellik kazanamamışlardır. Aylık veya on beş günlük uzun sürelerle çıkabilmişlerdir ${ }^{4}$.

Osmanlıdaki bu ilk iki gazetenin ardından belli bir süre boyunca (1798-1821) herhangi bir gazeteye rastlanmamaktadır. 1821 tarihinde İzmir' de yaşayan bir Fransız tüccarı, Osmanlı basın hayatında önemli bir yer kazanacak olan, Alexander Blacque, Spectateuer Oriental adında Fransızca haftalık bir gazete çıkard1. O dönemin en önemli olayı olan Rum İsyanı karşısında Osmanlı yanlısı bir politika izleyen bu gazete, Osmanlı padişahına, gazetenin önemi konusunda ilham kaynağı olmuştur ${ }^{5}$. Ancak Fransa ve Rusya gazetenin kapatılması için baskı yapınca, hükümet bu gazeteyi bir

3 İmre Karacson, "İbrahim Müteferrika", Tarih-i Osmani Encümeni Mecmuası, S.2, 1911, s.175-185.

4 Bkz. M.Nuri İnuğur, Basın ve Yayın Tarihi, Der Yayınları, İstanbul, 1993, s. 166 ; Selim Nüzhet Gerçek, Türk Gazeteciliği, İstanbul, 1931, s.15.

5 Orhan Koloğlu, "Türkçe Dışı Basın”, Tanzimattan Cumhuriyete Türkiye Ansiklopedisi(TCTA), c.3, s.94 ; 
ay süre ile kapatmıştır. Fransa'nın İzmir Konsolosu ise, daha da ileri giderek, gazetenin matbaalar1na el koymuştur. XIX. Yüzyılın önemli bir ticaret şehri olan İzmir'de Le Smyrneen ve Le Courrier de Smyrne adında Fransızca gazeteler de faaliyet sürdürdüler.

Padişah II. Mahmut, devletin görüşlerini uluslararası alanda ifade eden bir gazetenin çıkarılmasının önemini fark ederek, devletin görüşlerini savunan Fransız gazeteci A. Blacque'1 İstanbul'a çağırdı ${ }^{6}$. Kendisine, Osmanlı Devletinin çıkarlarını savunan Fransızca bir gazete çıkarma görevi verildi . Böylece 1831 yılında Le Moniteur Ottoman adında bir gazete çıkarıldı. Bu, yarı resmi bir gazete olup, Takvim-i Vekâyi'nin Fransızca versiyonu gibi bir işlev üstlenmiştir. Ancak A. Blacque'ın 1836'da ölümünden kısa bir süre sonra kapanmıştır. Daha sonra, 1846'da, A.Blacque'ın oğlu Edward, Padişah Abdülmecit (1839-1861) tarafından yarı resmi bir gazete ç1karmakla görevlendirilmiş ve yedi yıl boyunca yayınlanan bu gazeteye Courrier de Constantinople adı verilmiştir.

Osmanlı'daki Müslüman Türk toplumunun Türkçe gazete ile tanışması, XIX. Yüzyılın ilk yarısına, daha açık bir ifade ile 1830'lu yılların başlarına rastlamaktadır. Söz konusu bu yılların aynı zamanda Osmanlı Devletinin kararlı bir batılılaşma siyasetinin başlangıcına denk düşmesi bir tesadüf değildir. Gazete, Batılılaşma akımının bir gereği olarak ve yine onun gibi, devlet eliyle gelişmiştir. Padişah II. Mahmut, yapmayı tasarladığı reform hareketlerini içeride tanıtmak ve halkın bu reformlara desteğini sağlamak için bir gazetenin gerekli olduğuna inanıyordu.

1829 Edirne Antlaşmasından sonra idari reformlar yapmayı tasarlayan Padişah, sslahat meclislerini oluşturdu. İşte devletin resmi bir gazetesinin olması gerektiğine dair fikir, bu mecliste ortaya çıktı. Bu düşünceyi olumlu bulan padişah, ismini bizzat kendisinin koyduğu resmi gazete çıkarmak için ferman yayınlad1 ${ }^{8}$. Sonuçta, 1 Kasım 1831 tarihinde İstanbul'da ilk Türkçe gazete olan Takvim-i Vekâyi çıkarıldı.

Aslında Takvim-i Vekâyi'den önce Mısır Valisi Mehmet Ali Paşa tarafından Kahire'deki Bulak Matbaasında 20 Kasım 1828'de Vakayi-i Mısriyye adında Türkçe- Arapça bir gazete çıkarılmıştı'. Dolayısıyla Takvim-i Vekayi'nin ilk Türkçe gazete olması bile tartışmalıdır. Mısır'ın artık fiilen Osmanlı toprağı olmaktan çıkmaya başlaması ve Mısır'daki bu gazetenin 1890 yıllarında tamamen Arapça çıkması gibi etkenleri dikkate alırsak, ancak o zaman Takvim-i Vekâyi'nin Osmanlı' da ilk Türkçe gazete olduğunu söyleyebiliriz.

Devlet tarafından haftalık olmak üzere yayınlanan Takvim-i Vekâyi’nin giriş sayısındaki mukaddime yazısında, bugünün tarihi demek olan gazetelerin şeriata aykırı olmadığı, amacının halkı iç ve dış olaylar karşısında bilgilendirmek olduğu belirtilerek, eski vakanivüs tarihlerinin halka gerçekleri zamanında veremediğini ve şimdi gazete ile bu açığın kapatılacağı üzerinde du-

Zeki Arıkan, “Tanzimat ve Meşrutiyet Dönemlerinde İzmir Basını”, TCTA., c.3, İletişim Yay., İstanbul, 1985,s.103.

6 Alexander Blacque hakkında daha fazla bilgi için Bkz. Münir Aktepe, "Dünkü Fransızlar: Balck Bey ve Oğlu", İ.Ü.E.F. Tarih Dergisi, İstanbul, 1982, S.33, s.255-271 ; R. Ekrem Koçu, "Blacque”, İstanbul Ansiklopedisi, c.V, s.2834.

7 Necdet Ekinci, “Türk Basın Tarihinden Kesitler”, Türkler Ansiklopedisi, Yeni Türkiye Yay., Ankara, 2002, c.14, s.675.

8 Adnan Giz, “ilk Türk Gazetesinin Adı Nasıl Seçildi?”, Belgelerle Türk Tarihi Dergisi, S.64, 1973,s.24.

9 1830'lar boyunca birbirlerine düşman olmalarına rağmen, Batılılaşma konusunda birbirleri ile rekabet eden Padişah ve Misır Valisi birbirlerini sanki taklit ediyorlardı. Örneğin M. Ali Paşa da, 1833’te Moniteur Egyptien gazetesini yayınlanmasını sağladı. Bkz. Orhan Koloğlu, “illk Türkçe Gazete; Vakayi-i Misriye", Tarih ve Toplum Dergisi, c.58, Ekim 1988, s.9-12. 
ruluyordu ${ }^{10}$. Ayrıca Osmanlı tebası olan diğer unsurların konuştukları dilden de yayın yapılacağı belirtiliyordu.

Gerçek anlamda bir halk talebinden doğmayan, tamamen dönemin padişahının isteği doğrultusunda çıkarılan bu gazete yine de Türk Basın Tarihinde bir ilk olması bakımından önemlidir. Gazetenin dilinin halkın anlayabileceği sadelikte olmasına dikkat eden Padişah, Gazeteden sorumlu olan Esad Efendi'yi bu konuda uyarmıştır ${ }^{11}$. Osmanlı yazı dilinin ağırlı̆̆ının ilk kez bir padişah tarafından eleştirilmesi önemlidir. Devlet, ilk yıllarda gazetenin yayımı işine önem vermiş, Takvimhane-i Amire Matbaasını ve Takvimhâne Nezaretini kurmuş ve çok geçmeden Ermenice, Rumca, Arapça gibi dillerden de nüshalar yayımlamıştır. Hatta gazeteye yüksek rütbeli devlet adamlarının ve taşradaki memurların abone olması zorunlu kılınmıştı.

Basit bir düzende Umur-1 Dahiliye ve Umur-1 Hariciye ana başlıkları altında, her sayfada iki sütun şeklinde yayın hayatına başlayan Takvim-i Vekayi, zamanla bu başlıkları çoğaltarak, Fünun, Ticaret ve Es'ar gibi başlıklar da eklenerek, geliştirildi. İlk yedi ay haftalık olarak muntazam çıkmaya gayret ettikten sonra bir türlü düzenli çıkamadı. Hatta öyle ki, daha ikinci senesinde sadece 31 sayı çıkarılabildi ${ }^{12}$. 1840'tan sonra Mustafa Reşit Paşa, gazeteyi yeniden etkin kılmak istedi ise de, özellikle yarı resmi Türkçe gazetenin çıkması ile Takvim-i Vekâyi, giderek sadece resmi duyuruların yer aldığı bir bültene dönüştü.

Sonuç olarak Takvim-i Vekâyi ile ilgili olarak denilebilir ki, bütün eksikliklerine rağmen Türkçe basına öncülük ettiği için önemlidir. İlk Türk muhabir bu gazetede görevlendirilmiş, 11. sayısında ilk Türkçe ilana yer verilmiş, 8. sayısında ilk tercüme makaleye yer verilmiş, Müslüman halkın dış dünyayı, sınırlı da olsa, tanımasına imkan vermiş ve daha sonra özel Türkçe gazeteleri çıkaracak olanlara bir deneyim olmuştur. Türk basın hayatı için bir okul vazifesi görmüştür.

Kapitülasyonların tanıdığı geniş ayrıcalıklardan yararlanan ve İstanbul'a yerleşen bir İngiliz vatandaşı olan William Churchill, 1836 yılında Osmanlı Devletinden gazete çıkarma imtiyazını ald1. Bu imtiyazı dört yıl sonra kullanarak, 31 Temmuz 1840 tarihinde yarı resmi bir Türkçe gazete olan Ceride-i Havadis'i çıkardı. W.Churchill, ilk sayıda yazdığı mukaddimede, gazetenin halkın bilgisini artırdı ğını, diğer ülkelerde olup bitenlerin aktarıldığını, halkın merak hislerinin arttığını ve bu yolla meslek ve ticaret hayatının gelişmesinin önünün açıldığını belirtiyordu ${ }^{13}$

$\mathrm{Bu}$ gazete ilk yıllarında halktan hemen hiçbir ilgi görememiş ve hatta ilk sayıları bedava dağıtılmıştır. 1843 yılında sadece 150 civarında abonesi olan bu gazetenin içerik olarak Takvim-i Vekâyi'den farklı olduğu özellikler vardır. Özellikle dış haberlere geniş yer veren gazete, yurt d1şında muhabirlere sahip olmakla basında bir yenilik gerçekleştirmiştir. Özellikle Kırım Savaşında (1853-1856) Ceride'ye olan ilgi çok artmış ve savaş muhabirliği konusunda öncü olmuştur ${ }^{14}$. Ayrıca ilave gazete vermek konusunda da bir ilk yaşatmıştır. Yarı resmi olan bu gazete özel Türkçe gazeteciliğe geçişte bir basamak teşkil etmesi bakımından da önemlidir.

10 Takvim-i Vekâyi’nin bu giriş yazısının tamamı için Bkz. Nesimi Yazıcı, Takvim-i Vekâyi: Belgeler, Gazi Üniversitesi Basın Yayın Yüksek Okulu Yayını, Ankara, 1983, s.5.

11 Padişah II. Mahmut, gazetenin 149. sayısında Varna gezisi ile ilgili verilen haberin dilini ağır bulmuştu. Bkz. Lutfi Efendi, Tarih, c.5, s.90.

12 Gazetenin pek düzensiz aralıklarla çıkması, dönemin devlet adamları arasında alay konusu bile oluyordu. Rıfat Paşa’nın yakıştırmasılyla “Tarihi pek yeni ama kendisi pek eski” bir gazete haline dönüşmüştü. Bkz. Mustafa Nihat, "Yüzyıllık Gazeteciliğimiz”, Ayın Tarihi, S.46-47, Ankara, 1928, s.2903.

13 Nesimi Yazıc1, “Takvim-i Vekayi ve Ceride-i Havadis’in Mukadimmelerinin Karşılaştırılması”, Gazi Üniversitesi Basın Yayın Yüksek Okulu Dergisi, S.6,Ankara, 1984, s.69.

14 Hasan Refik Ertuğ, Basın Yayın Hareketleri Tarihi, c.1, İstanbul, 1959, s.150. 
Ceride-i Havadis gazetesi biçimsel olarak Takvim-i Vekâyi'ye benzemekte, tıpkı onun gibi Dahiliye ve Hariciye ana başlıklarını kullanmış, önce iki sütunlu bir sayfa düzeni kullanmış, 1847 'den sonra üç sütuna çıkarmıştır. Gazetenin üçüncü başlığı olan İlanât başlı̆̆ı çok çeşitli ilanları içermektedir. İlk ölüm ve ilk iş ilanları, gemi tarifeleri, kiralık ve satılık ilanları bu gazetede çıkmış, hatta İstanbul'un günlük hava sıcaklıklarını bile vermiştir's ${ }^{15}$.

Gazetenin düzenli aralıklarla yayınlandığını söylemek zordur. Başlangıçta haftalık, sonra da on günlük süre ile yayınlanmışsa da, ilk yıllarında çok seyrek çıkmıştır. İlk beş yılda sadece 210 sayı çıkmıştır. Gazete devlet hazinesinden parasal yardım almakla kalmıyor, aynı zamanda Takvimhâne-i Amire'den de eleman ve teknik destek alıyordu ${ }^{16}$.

\section{Bir Osmanlı Aydını Olarak İbrahim Şinasi Efendi (1824 -1871)}

Tasvîr-i Efkâr'ın basın tarihimizdeki önemini daha iyi kavramak için, gazetenin kurucusu olan Şinasi'nin hayatı hakkında bilgi sahibi olmak, eğitim sürecini bilmek ve buradan düşünce dünyasına girmek, eserlerini tanımak gerekir. Onun hayat öyküsünü, yurt dışındaki yaşamını, devlet kademelerindeki görevlerini anlamadan Tasvîr-i Efkâr'ın yayıncılık politikasını anlayamayız.

İbrahim Şinasi Efendi, Müslüman ve Türk bir ailenin çocuğu olarak, 1824 y1lında İstanbul'da doğmuştur ${ }^{17}$. Osmanlı ordusunda topçu yüzbaşı olan babası, 1828-1829 Osmanl1-Rus savaşında hayatını kaybetmiştir. Şinasi'nin çocukluğu ve ilk yetişme dönemi, II.Mahmud'un islahatlarının henüz başlangıç aşamasında olduğu döneme rastlamaktadır. Eğitim hayatına mahalle mektebinde başlayan Şinasi, henüz orta öğrenim kurumları oluşmadığı için, ilköğreniminin hemen ardından Tophane Müşirliği kalem odalarında çalışmaya başladı ${ }^{18}$. Söz konusu bu ve benzeri devlet daireleri bir tür okul görevi görüyorlard1.

Oldukça genç sayılabilecek bir yaşta kalem hayatına başlaması, Şinasi’nin titiz gazeteciliği ve dil bilimciliği üzerinde etkili olacaktır. Öğrenmeye çok hevesli, zeki ve çalışkan bir genç olan Şinasi, önce Arapça, ardından Farsça'yı özel çabaları ve aldığı derslerle öğrendi ${ }^{19}$. Genç Şinasi'nin hayatında önemli bir dönüm noktası da, Fransız zabitlerinden olup, daha sonra Müslümanlığı seçen Reşad Bey (Chateauneuf) ile tanışmasıdır. İstanbul'da askeri uzman olarak çalışan ve bazen Şinasi'nin çalıştığı kuruma da uğrayan Reşad Bey, hayattaki yegâne ihtirasını, ilim ve hüner öğrenmek olarak ifade eden Şinasi'ye Fransızca öğretmeye başladı. Böylece Şinasi için Batı dünyasına giden zihinsel kapı ilk kez açılıyordu.

Çalıştığı kurumda çalışkanlığ 1 ile dikkat çekerek, rütbesini yükseltti. Bu arada şiirle de uğraşan Şinasi, manzum tarihi kitabeler yazma konusunda kendisini geliştirdi. Onun yazdığı bu ilk edebi dizeler, bazı köprülere ve çeşmelere kitabe oldu. 3 Kasım 1839'da Gülhane Hatı'’nın ilanı ile Tanzimat Dönemi denilen yeni bir döneme giren Osmanlı Devleti, önemli bir Batılılaşma hamlesi

15 Mustafa Nihat, a.g.m., s.2940.

16 Enver Behnan Şapolyo, Türk Gazetecilik Tarihi ve Her Yönüyle Basın, Güven Matbaası, Ankara, 1969, s.110.

17 Ahmet Rasim, Şinasi ile ilgili yazdığ kitabında, onun ailevi bilgilerini bizzat oğlundan naklederekvermektedir. Bu konuda ayrıntılı bilgiler sunmaktadır. Bkz. Ahmet Rasim, İlkBüyük MuharrirlerdenŞinasi, İstanbul 1927.

18 Ömer Faruk Akün, "Şinasi”, İslam Ansiklopedisi, c.11, İstanbul, 1979, s.545.

19 Mahmut Kemal İnal, Son Asır Türk Şairleri, Milli Eğitim Basımevi, c.10, İstanbul, 1940, s.1800. 
başlattı. Bu dönemin önemli mimarlarından olan ve Şinasi'nin de hayran olduğu Mustafa Reşit Paşa, Avrupa'ya öğrenci gönderiyordu. Bu durum, Fransızcasını geliştirmek ve Avrupa'yı tanımak isteyen Şinasi Efendi için bir fırsat idi. Tophane Müşiri Fethi Paşa'nın aracılığı ve Mustafa Reşit Paşa'nın da uygun görmesi ve Padişahın iradesi ile 1849 yılında Paris'e gitti ${ }^{20}$.

Şinasi'nin dünya görüşünün şekillenmesinde, onun Paris’teki bu ilk yıllarının rolü büyüktür. O 1849'dan 1855 yılının başlarına kadar, hatırı sayılır bir süre için, burada kaldı. Bu süre içinde Avrupa'daki gelişmeleri bizzat görme şansını yakaladı. Osmanlı ile Avrupa Devletleri arasındaki farkları görmüş oldu. Ayrıca Paris’teki ünlü Şarkiyatçı bilim adamları ve edebiyatçılarla tanıştı. De Sacy ailesi, Lamartine, Ernest Renan gibi önemli insanlarla tanışan Şinasi, 1851 yılında Paris’te Doğu Dünyası ile ilgili araştırmalar yapan ve Journal Asiatique Dergisini çıkaran çok önemli bir kuruma, Societe Asiatique Cemiyetine üye oldu. Şinasi'nin Paris’teki tahsil hayatında gösterdiği başarılardan memnun kalan ve kendisini daha da teşvik etmek isteyen Mustafa Reşit Paşa, maaşına zam yapılmasını sağladı. Şinasi'nin Fransa'da bir yandan maliye öğrenimi, bir yandan tabii bilimler ile uğraştığı bilinse de, onun asıl ilgi alanı Edebiyat, Dil ve sosyal bilimler oldu. Dolaylı da olsa bir siyasi dünya görüşü edindi²1 .

Avrupa'daki öğreniminin ardından 1854 yılı sonlarında İstanbul'a dönen Şinasi, bir süre daha Tophane Müşirliğinde çalıştıktan sonra daha yüksek bir görev olan Meclis-i Maarif üyeliğine atandı. Osmanlının gelişmesi için eğitimin önemli olduğunu, eğitimin yaygınlaşması, halkın anlayacağı bir dille sunulması gerektiğini düşünen Şinasi Efendi, istediği nitelikte önemli bir göreve getirilmiş oldu. Artık devletin eğitim programlarının ortaya çıkmasında, şekillenmesinde onun da katkısı olabilecekti² ${ }^{2}$. Şinasi, bu görevini 1860'ta gazetecilik hayatına başladıktan sonra da sürdürdü. Ancak özellikle gazetesi aracılığ 1 ile savunduğu kimi görüşlerinden rahatsız olan Sadrazam Âlî Paşa'nın talimatı ile görevinden azledildi. Tam olarak kesin olmayan nedenlerden ötürü 1865 yılında dostu Giampetri'nin aracılığıyla Paris'e kaçan Şinasi, 1870 yılına kadar burada kaldı. Bu süre içerisinde kendini dil çalışmalarına adayan Şinasi'nin en büyük hayali Türk dilinin büyük bir sözlüğünü hazırlamaktı. Ancak idealindeki böyle bir çalışmayı tamamlayamadı. 1870 yılında İstanbul'a tekrar döndü. Bir süre sonra da rahatsılanarak, 12 Eylül 1871'de vefat etti.

Şinasi, Tanzimat reformlarını destekleyen, ancak bunların daha da geliştirilmesinden yana olan ve Osmanlı devletinin çağdaş bir hukuk devleti olmasını savunan tipik bir Tanzimat aydınıdır. $\mathrm{O}$, Padişahın sınırsız, sorumsuz otoritesine karşı gerektiğinde padişaha bile haddini bildiren bir yasa gücünden yanadır ${ }^{23}$. Ancak parlamentolu bir anayasayı hiçbir zaman açıkça savunmamıştır. Şinasi'nin asıl önemi bir yandan Osmanlı devlet ve aydın dilinin halka inmesini savunurken, diğer yandan dilimize özellikle Batı'dan esinlenerek, yeni kavramları yerleştirme çabasıdır. Bu çok önemli anlamlar ve kavramlardan bazıları şöyle sıralanabilir: "Umûm Efkâr, Heyet-i Íctimaiyye, Mukteseb Haklar, Halk, Vatan, Medeni Milletler, Maarif Kuvveti .....v.s.”. İşte bu ve benzeri yeni kavramlardan hareket eden Şinasi, esin kaynağını Batı'dan alan yeni bir dünya görüşü inşa etmeye

20 Ahmet Refik, "Şinasi’nin Berâ-yı Tahsil Paris’e Gitmesi", T.T.E.M., No: 9, Ankara, 1925, s.215-216 ; Bernard Lewis, Ebu ziya Tevfik'e dayanarak, Şinasi'nin 1848 İhtilali’nde yer aldığını ve hatta Pantheon'a cumhuriyet bayrağı diktiğini yazarak, yanlış bir bilgiyi aynen devam etmektedir. Bkz. Bernard Lewis, Modern Türkiye'nin Doğuşu, çev.Metin Kıratl1, 8.bs., T.T.K. Yay., Ankara, 2000, s.136.

21 Kenan Akyüz, "Şinasi’nin Fransa'daki Öğrenimi ile İlgili Belgeler”, Türk Dili, No: 31 1954, s.403.

22 Şinasi ve Meclis-i Maarif için Bkz. Mahmut Cevad, Maârif-i Umûmiye Nezareti Tarihçe-i Teşkilat ve İcraatı, M.E.B. Yay., Ankara, 2002, s.198.

23 Tanzimat'ın mimarı olan Reşit Paşa'ya ithaf ettiği bir şiirinde şöyle diyordu: "Bir ıtıknâmedir insana senin kanunun / Bildirir haddini sultana senin kanunun.” Bkz. Hikmet Dizdaroğlu, Şinasi: Hayatı ve Eserleri, İstanbul, 1954, s.43. 
çalışı1 ${ }^{24}$.

Şinasi, şiir ve düzyazı türlerinde çok sayıda eser kaleme aldı. Düşünce tarihimizde özellikle düzyazı alanındaki eserleri ve yazıları ile önem kazandı. Bunun yanı sıra çeviri eserler de yayınladi. Türk edebiyatının ilk telif tiyatro eseri olan Şair Evlenmesi adlı komedi oyununda toplumda hâkim olan görücülük usulü gibi geleneksel adetlerin eleştirisini yaptı. Türk Edebiyatında halka inme akımını başlatan Şinasi, bin beş yüz civarında Türk atasözünün derlendiği bir eser yayınlad1. Durûb-u Emsâl-i Osmaniye adındaki bu önemli eseri titizlikle hazırlayarak, kendi matbaasında bastırdı. Yazdığı şiirlerin bazılarını Müntehabât-ı Eş' $a r$ adı altında bir kitap halinde topladı. Fransızcadan tercüme ettiği şiirleri ise, Tercüme-i Manzume adıyla yayımladı. Bunun yanı sıra gramer konuları ile ilgili eser yazdığı biliniyorsa da, elde mevcut bir baskısı bulunmamaktadır ${ }^{25}$.

\section{Özel Türk Gazetelerinin Ortaya Çıkmasında Şinasi’nin Rolü}

Osmanlı Devletinde doğrudan doğruya Türk aydınları tarafından çıkarılan ve gerçek anlamda bir gazete karakterini daha çok taşıyan Tercüman-1 Ahvâl, ilk özel Türkçe gazetedir. 21 Ekim 1860 tarihinde Agah Efendi tarafından çıkarılan bu gazete ile Türk Basın Tarihi için yeni bir dönem başlamaktadır.

Gazetenin imtiyaz sahibi olan Agah Efendi, 1832'de dünyaya gelmiş, aslen Yozgatlı köklü bir aile olan Çapanoğullarından gelen zengin bir Türk gencidir. Galatasaray Tıbbiye Mektebini bitirdikten sonra Paris elçisi Sadık Rıfat Paşa'nın katipliğine girmiş ve Fransa'da bulunmuştur. 1860 yılında gazete çıkardığında 28 yaşında bulunan bu aydın genç, aynı zamanda Tercüme Bürosunda da çalışıyordu ${ }^{26}$.

Agah Efendi'yi bir gazete çıkarması konusunda Şinasi ikna etmiştir²7.Tercüman-1 Ahvâl Gazetesinin başyazarı Şinasi Efendi, gazetenin ilk sayısında çok önemli bir giriş yazısı kaleme aldı. Düşünce tarihimizde, Osmanlının aydın Türk kesiminin ulaştığı yeni seviyeyi göstermesi bakımından önemli olan bu yazıda şöyle deniliyordu' ${ }^{28}$ :

"Madem ki; bir toplum içinde yaşayan halk, bunca yasal yükümlülükler altına alınmıştır. O zaman sözle ve yazı ile vatanın menfaatine dair görüş beyan etmeyi kazanılmış haklarından sayar. $\mathrm{Bu}$ gerçeği anlamak için Maarif kuvveti ile zihni açılmış olan milletlerin yalnız politika gazetelerine bakmak bile yeterlidir. Aslında devlet, Tanzimat sayesinde, millete ifade hürriyeti hakk1 vermiştir. Osmanlı devletinde, Müslüman olmayan unsurların kendi dillerinde çıkardıkları gazeteleri, serbestçe yayınlanmaktadır. Fakat bu zamana dek Müslüman milletin hiçbir özel gazetesi çıkarılamamıştır.

24 O dönemde Avrupa'da kullanılan Jeunne tabirinin gerçek anlamda Şinasi'ye uyduğunu ve onun Laikliğin ve ulusçuluğun öncüsü sayılması gerektiğini belirten notlar için Bkz. Niyazi Berkes, Türkiye'de Çağdaşlaşma, 7.bs., Yapı Kredi Yayınlar, İstanbul, 2004, s.261-290.

25 A.Hamdi Tanpınar, 19. Asır Türk Edebiyatı Tarihi, 6.bs., Çağlayan Kitabevi, İstanbul, 1985, s.191 ; Nihad Sami Banarl, Resimli Türk Edebiyatı Tarihi, M.E.B. Yay., İstanbul, 1978, s.858-868.

26 Server İskit, Hususi İlk Türkçe Gazetemiz Tercüman-ı Ahvâl ve Agah Efendi, Ulus Basımevi, Ankara, 1937, s.20.

27 Agah Efendi, Tercüman-1 Ahvâl'in ilk sayısında İhtar başlığı altında yazdığı yazıda, Şinasi'nin kendisini sözleri ve fiili yardımları ile teşvik ettiğini belirtmiştir. Bkz. Tercüman-ı Ahvâl, S.1 (6 Rebiülahir 1277).

28 Biraz sadeleştirerek, verdiğimiz bu önemli yazı için Bkz. Banarlı, a.g.e., s.826 ; Tanpınar, a.g.e., s.211 ; S. İskit, a.g.e., s.20. 
Şimdi bu gazete iç ve dış durumu yansıtan haberleri ve çeşitli faydalı bilgileri ve değişik konulardaki maddeleri yayınlamak için bir aracı olacağından adı Tercüman-1 Ahvâl olarak konulmuştur. Söz, ihtiyaçları, talepleri ifade etmeye yarayan vergisi olduğu gibi, insan aklının en güzel icadı olan yazı ise, sözün kalemle tasviridir. Bu gerçeklerden yola çıkarak, bütün halkın kolaylıkla anlayabileceği düzeyde bu gazeteyi çıkarak bir gereklilik oldu."

Tercüman-1 Ahvâl, haftalık bir gazete olarak, Pazar günleri başladığı yayın hayatında bir süre sonra haftada iki ve üç defa şeklinde yayınlanmaya başlamıştır. İçeriği ve genel düzeni açısından önceki Türkçe gazetelerden daha gelişmiştir ${ }^{29}$. Sadece bir haber gazetesi değil, aynı zamanda bir fikir gazetesi işlevini de üstlenmiştir. Zaman zaman hükümet politikalarını eleştiri konusu yapabilmiş ve bu yüzden Mayıs 1861 tarihinde iki hafta süre ile hükümet tarafından kapatılmıştır. Bu, basın tarihimizdeki ilk gazete kapatılmasıdır. Şinasi'nin deyimiyle sorumluluklarında fazla haklara sahip olan azınlık gazetelerine dokunamayan hükümet, ilk Türkçe gazetelere karşı hiç müsamaha göstermiyordu ${ }^{30}$.

Şinasi'nin yayın yönetmenliği altında faaliyetine başlayan bu özel Türk gazetesi, imzalı başyazı geleneği, siyasi makale ve tefrika konusunda öncü olmuştur. Şinasi'nin eseri olan Şair Evlenmesi, basın tarihimizin ilk tefrikası olarak, burada yayınlanmıştır. Özel Türkçe gazeteciliğin devlet memuru sıfatı taşıyan bir Türk tarafından açılması, devletten hazine yardımı almakta olan Ceride-i Havadis'i tedirgin etmiş ve ayrıcalıklarının elinden gideceğini düşünen Churchill, Tercüman-1 Ahval ile polemiklere girişmiştir. Gazetecilik tarihimizin ilk gazeteler arası polemik olayı böylece geçekleşmiştir.

Şinasi, gazetenin 24. sayısından itibaren ayrılmış, burada sadece altı ay çalışmasına rağmen gazeteye damgasını vurmuştur. Onun ayrılmasından bir süre sonra gazetenin boyutu küçültüldü. Tasvîr-i Efkâr Gazetesinin çıkması ile ikinci plana düştü. Gazetenin sahibi olan Agah Efendi, hiçbir zaman devlet adamlığı kimliğini bırakmamış, bütün enerjisini sadece gazeteye vermemiştir. Tercüman-1 Ahvâl, biraz da sahibinin bu tercihinin bir sonucu olarak istenilen seviyeyi bir türlü yakalayamamıştır. Dikkat çekici bir okuyucu kitlesine ulaşamamış, satış miktarı bakımından Tasvîr-i Efkâr'dan çok daha düşük seviyede kalmıştır.

Agah Efendi'nin Yeni Osmanlı Cemiyetine girmesi, siyasi muhalefet işine bulaşması ve 1867 yılında yurt dışına kaçması, Tercüman-1 Ahvâl'in yayınını zor duruma soktu. Sonuçta aynı yıl, gazete kapand1. Liberal eğilimli özel bir Türkçe gazete olarak kabul gören Tercüman-1 Ahvâl, Türk toplumunun siyasal ve kültürel uyanışında belirli bir rol oynamış ve Türk basın tarihinde bir çığır açmıştır. Gazetenin sahibi olan Agah Efendi ise, profesyonel gazetecilik mesleğinin kurucusu olmuştur. Osmanlıda yaşayan Türkler arasında o, ilk gazete sahibi, ilk yazı işleri müdürü ve aynı zamanda ilk başyazardır.

\section{Tasvir-i Efkâr Gazetesinin Çıkarılması ve Gazetenin Bazı Özellikleri}

İstanbul'da çıkarılan ilk özel Türkçe gazete olan Tercüman-1 Ahvâl'in sadece ilk yirmi dört sayısında görev alan İbrahim Şinasi, 12 Mart 1861 tarihinde bu gazeteden ayrıldı. Birçok araştırmacı tarafından Tercüman-1 Ahvâlden Şinasi'nin ayrılma nedeni hakkında çeşitli nedenler ileri sürülmüşse de, bu konuda kesin bir bilgi yoktur. Onun asıl amacı, tek başına sahip olduğu bir gazete çıkarmaktı. Aslında Tercüman-1 Ahvâl, bir bakıma Şinasi'ye kendi başına çıkaracağı bir

\footnotetext{
29 İnuğur, a.g.e., s. 186.

30 Server İskit, Türkiye’de Matbuat İdareleri ve Politikalarl, Ankara, 1943, s. 12.
} 
gazete için bir atlama taşı hizmetini görmüştür ${ }^{31}$.

Tercüman-1 Ahvâl'den ayrıldıktan kısa bir süre sonra özel bir gazete çıkarmak için Babıli'ye müracaat eden Şinasi, hükümetten gerekli olan izni 2 Temmuz 1861 tarihinde ald1 ${ }^{32}$. Gazete çıkarmak için gerekli olan izni aldıktan sonra, bir yıl sürecek olan titiz ve uzun bir çalışmanın içine giren Şinasi, döneminin en tertipli gazetesini yayımlamak istiyordu. Gazete basmak için işe önce İstanbul'un Hamidiye semtinde özel bir matbaa kurarak başladı. Döneminin en güzel harfleri olarak kabul edilen Kazasker Yesârizâde İzzet Efendi hattı ile dökülmüş olan matbaasını gazete ve kitap basmaya uygun hale getirdi.

Neticede bir memur olan Şinasi'nin böyle büyük bir matbaayı kurabilmek için gereken maddi imkânı nasıl elde ettiği açıç̧a bilinmemekle beraber, Şehzâde Murat ve/veya zengin Misır prenslerinden Fazıl Mustafa Paşa'nın desteklemiş olabilecekleri düşünülmektedir. Ayrıca Şinasi'nin Avrupa'dan tanıdığg dostlarının, özellikle matbaacı dostu Jean Pietri'nin (Giampetri) destekleri dikkat çekicidir ${ }^{33}$.

Şinasi'nin yayın izni aldıktan sonra gazete çıkarmakta gecikmesinin tek nedeni titiz çalışma isteği değildi. Dönemin sadrazamları ile olan ilişkisi onun gazete çıkarmasında bir şekilde olumlu ya da olumsuz etkide bulunuyordu. Bu dönemde Osmanlı Devletinde sık sık sadrazam değişmekte idi. Kıbrıslı Mehmet Paşa zamanında gazete ruhsatı alan Şinasi, daha sonra muhalif olduğu Âlî Paşa'nın sadrazam olması nedeni ile yayın işini geciktirmek zorunda kaldı. Sonunda ancak Fuat Paşa'nın sadrazam olması ile uygun ortamı yakalayan Şinasi, gazetesini yayınladı. Ayrıca Şinasi'nin Avrupalı doğu bilimci dostları da bu olaya sevinmiş ve Jean Pietri, daha hazırlıklar sürerken, Tasvîr-i Efkârın çıkacağını müjdelemiştir.

Şinasi’nin gazetesini yayınlaması, değiş̧ik çevrelerde farklı tepkilerle karşılandı. MüslümanTürk aydın çevrelerinde böyle gelişmiş bir gazetenin çıkması sevinçle karşılandı. Şinasi'nin daha önce çalıştığı Tercüman-1 Ahvâl, bir vefa örneği göstererek Tasvir'in çıkmasını kutladı. ${ }^{34}$. Kutlamanın ötesinde bir sevinçle Tasvir'in çıkmasını destekleyen yayın organlarından biri de Münif' in çıkardığı Mecmua-i Fünun'dur. Bu yeni gazete ile hemen hemen eş zamanlı olarak yayın hayatına başlayan mecmuasını vatan evlatlarına hizmet niyetiyle yola çıkan iki kardeş şeklinde nitelendiren Münif, yazısını şöyle sürdürüyordu:

"Meclis-i Maarif azasından izzetlü Şinasi Efendinin biraz vakitten berü tanzim ve tehiyyesiyle iştigal eylediği gazete iş bu sene- $i$ hicriye ibtidasında (Tasvir- $i$ Efkar) ünvantyla safha-i pira-yl zuhur ve muntazırı olan dil-teşne-gân havadis ve ahbara bais hatt mevfur olmuştur. Muharririn ehliyet ve fetânetinden dahi memul olduğu vechle gazete-i mezkurun hüsn-i tertib ve insicamı şayan-l tahsin ve erbab-ı himmet ve hamiyet taraflarından mazhar-ı teşci ve teşvik olduğu halde ileride bir kat daha kesb-i vüs 'at ve intizam edeceği nezd-i acizânemizde rehîn-i rütbe-i ilm el yakîndir "35.

Ancak Osmanlı basın hayatındaki tekelinin sarsılacağını düşünen Ceride-i Havâdis'in sahibi Churchill, özel Türkçe gazetelerin yayın hayatına başlamasından pek memnun olmadi ${ }^{36}$. Yayın

\footnotetext{
31 Ömer Faruk Akün, "Şinasi”, İslam Ansiklopedisi, c.11, İstanbul, 1979, s.549.

32 Verilen resmi izin belgelerinde şöyle deniliyordu: “...Meclis-i Maarif azasından Şinasi Efendi’ye devlet aleyhinde yazı yazılmamak şartıyla Türkçe jurnal çıkarmasına ruhsat itası....” Bkz. BOA, MKT. MVL, 127/91 ; BOA, İ. MVL, 448/19983.

33 Akün, a.g.m., s. 549.

34 Bkz. Tercüman-ı Ahvâl, No: 199, (2 Muharrem 1279).

35 ; Münif, "Zuhûr-i Tasvîr-i Efkâr”, Мecmua-i Fünun, No:1, s.46.

36 Ziyad Ebüzziya, Şinasi, İletişim Yay., İstanbul, 1997, s.202.
} 
hayatına başlayan Tasvir-i Efkâr'ı kutlayan yazı yazmadığı gibi, çok geçmeden bu yeni gazete aleyhinde yazılara başladı.

27 Haziran 1862 Cuma günü (Hicri 1278 senesinin son günü) Türk Basın Tarihinde çok önemli bir yeri olan Türkçe özel bir gazete "Tasvîr-i Efkâr" adıyla çıktı. Gazetenin adını bizzat seçen Şinasi, bu adı seçmekle, basit bir günlük olay gazetesi değil de, bir düşünce ve yorum gazetesi çıkaracağının işaretini veriyordu. Önceki gazetelerden çok farklı bir düşünce ve nitelikte çıkan Tasvîr-i Efkâr, İstanbul'da haftada iki gün (Çarşamba ve Cumartesi) olarak yayın hayatına başladi. 7 Haziran 1868 tarihli 592. sayıdan itibaren yayını haftada beş güne çıkartan gazete, yaklaşık üç ay sonra tekrar haftada iki günlük yayın politikasına döndü.

Gazetenin başlığının hemen altında, parantez içinde "Havâdis ve Maârife Dair Osmanlı Gazetesi" ibaresi yer almaktadır. Bu ibarenin altında boydan boya iki satır halinde dizilmiş olarak, "Haftada iki defa İstanbul'da tab've neşr olunur. Gazetehânesi Hamidiye'de kâindir. Maârif ve umûr-u hayriye ilanâtı mecânen basılır" denildikten sonra gazetenin fiyatı hakkında bilgiler yer almaktadir ${ }^{37}$.

Toplam dört sayfa olarak yayın hayatına başlayan Tasvîr-i Efkâr'da her sayfa çift sütun şeklinde ayrılmış olup, yazılar "Havâdis-i Dahiliye" ve "Havâdis-i Hariciye" olmak üzere iki ana başlık altında toplanmıştır. Memleketin iç olaylarına ayrılan ana başlığın altındaki haberler, "Payitaht" ve "Eyalât" olarak ayrılmıştır. Payitaht başlığı altında, genellikle yapılan atamalar, çeşitli resmi yazılar, Hatt-1 Hümâyûnlar ve İstanbul ile ilgili çeşitli haberler bulunmaktadır. Bunun dışında Osmanlı memleketini oluşturan eyaletlerle ilgili çeşitli haberler yer almaktadır.

Taşradan gelen bu haberlerin kaynağı, bazı eyaletlerde bulunan kişilerin gönderdikleri özel mektuplar ile telgraflardır. Dönemin bütün gazetelerinde olduğu gibi Tasvîr-i Efkâr da, ülke çapında düzenli faaliyet gösteren resmi muhabir ekibinden yoksundur. 1860'ların başlarında henüz böyle bir meslek gelişmemiştir. Yine de çeşitli eyaletlerde özel haber kaynaklarına sahip olmaya çalışan Tasvîr-i Efkâr, haber kaynakları bakımından benzerlerine oranla daha gelişmiştir. 1864 yılında yayımlanan idari nizamnâmenin sonucu olarak vilayetlerin kurulmasıyla birlikte çeşitli vilayet gazeteleri ortaya çıktı. İşte Tasvîr-i Efkâr'ın taşra ile ilgili en önemli haber kaynağı bu yerel gazetelerdir. Bu tarihten sonra "Havâdis-i Dahiliye" içinde yer alan "Eyalet" başlı̆̆ının "Vilayet" olarak değiştirildiği görülmektedir.

Tasvîr-i Efkâr Gazetesinin özellikle resmi haberleri verirken, devletin resmi gazetesi olan Takvîm-i vekâyi'den haber kaynağı olarak yararlandığ1 ve bu türden haberlerin çoğunda kaynak olarak bu gazetenin adının açıkça belirtilmesinden anlıyoruz. Ayrıca Osmanlı memleketinde yayın hayatını sürdüren birçok yerli ve yabancı gazeteden de yararlandığ 1 görülmektedir. İstanbul'da faaliyet gösteren yabanc1 gazetelerden özellikle Courrier d'Orient, La Turquie, Levant Herald gibi gazeteler önemli haber kaynakları arasındadır.

Dünyadaki gelişmeleri aktaran "Havâdis-i Hariciye" başlığının altında ise, Avrupa, Asya, Afrika ve Amerika bölümleri bulunmaktadır. Söz konusu yerlerle ilgili çeşitli haberlerin verildiği bu bölümün haber kaynağı genellikle yabancı gazetelerden yapılmış alıntılardır. Bu bölümdeki haberlerin büyük çoğunluğu, yabancı devletlerin birbirleri ile ilişkileri ve o devletlerin içinde yaşanan ilginç gelişmelerdir. Özellikle Avrupa devletlerinin Osmanlı ile ilişkilerini irdeleyen yazılara daha az yer verilmesi düşündürücüdür.

Gazetede, iç ve dış olayları ele alan iki ana başlığın dışında "Illanât" ve "Tefrika" adında 
iki başlık daha bulunmaktadır ${ }^{38}$. Gazete çok çeşitli ilanlarla maddi destek sağlamaya çalışmıştır. Çeşitli ihaleler, müzayedeler, satışlar, sağlık ilanları gibi duyurular dönemin sosyal ve ekonomik yaşamı hakkında ipuçları vermektedir. Ayrıca gazetenin çok önemli bir bölümü olan tefrika bölümünde ise, çeşitli konularda yazılan eserler, bölümler halinde yayımlanmıştır.

1862 yılından 1869 yılına kadar yedi yıl boyunca, oldukça düzenli bir biçimde yayın hayatını sürdüren Tasvîr-i Efkâr'ın 830 sayı çıktığı söylense de, kütüphanelerde 743. sayıya kadar nüsha mevcuttur ${ }^{39}$. Gazeteyi çıkaranların aynı zamanda devlet kademelerinde görev almaları, yaptıkları muhalefetin sonucu olarak zaman zaman yaşadıkları zorluklar, Tasvir-i Efkâr'ın daha fazla sürmesini engelledi. Gazetenin 1869 yılı sonlarına doğru kendiliğinden kapandığı anlaşılmaktadır.

Şinasi, gazetenin hem sahibi, hem de başyazarıdır. Onun aynı zamanda bir düzeltmen olarak çalıştı̆̆ı, yazıların imla ve noktalamalarına özen gösterdiği görülmektedir. Bu özenin sonucu olarak Tasvîr-i Efkâr, düzenli, tertipli, disiplinli bir gazete olarak farklı bir yer edinmiştir. 1864 Basın Nizamnamesinin getirdiği yasal bir zorunluluktan hareketle gazetenin 261. sayısından itibaren sahibinin adı yazılmıştır. Buna göre, "Sahib-i Imtiyazl” İbrahim Şinasi Efendi'dir. Ancak onun gazeteyi bir süre sonra bırakıp, Avrupa'ya gitmesi üzerine 29 Ocak 1865 tarihli (Hicri 2 Ramazan 1281 senesi) 269. sayıdan itibaren imtiyaz sahibinin vekili olarak Raşid ismine rastlanmaktadır. Gazetenin elimizde mevcut 22 Aralık 1869 tarihli 682. Sayısının sonunda da Raşid Efendi'nin imzasi mevcuttur.

Bir başyazar olarak gazetenin ilk sayısında yayınladığı mukaddime yazısında daha önce Tercüman-1 Ahvâl'de kaleme aldığ1 ön sözündeki görüşlerini bir bakıma tekrarlayan Şinasi, gazetecilikteki amacını ve beklentilerini ortaya koydu. Bu mukaddimeye göre, devlet, milletin vekilidir. Devletin gücü, halka götürdüğü iyi hizmetlerden doğar. Devlet, ancak toplumla var olur. Gazeteler ise, halkın bu hizmetler hakkındaki düşüncelerinin tercümanıdır. Ona göre gazete, kamuoyu oluşturmada ve devletle halk arasındaki bağı kurmada önemli bir vasıtadır ${ }^{40}$.

Halkın anlayabileceği bir dille yazmaya çok önem veren Şinasi, bir yazar olarak altına imzasını atmaktan çekindiği yazılarını ince taktiklerle yayımlamayı başarıyordu. Genellikle devlet yönetimini eleştiren nitelikteki bu tür makaleleri, arkadaşı olan Jean Pietri'nin Courrier d'Orient Gazetesine Fransızca olarak yazıp, sonra da oradan alıntı şeklinde kendi gazetesine alıyordu. Ancak yine de Babıali, bu nispeten serbest fikirli gazetenin muhalif tavrından rahatsız olarak, Şinasi'nin devletteki görevine son verdi¹ ${ }^{4}$. Böylece hem devlet görevini ve hem de gazete işini ancak 106. sayıya kadar sürdürebildi.

Gazetenin güçlü bir yazar kadrosunun olduğu ve Namık Kemal, Recaizade Ekrem, Kayazade Reşat, Ahmet Vefik gibi dönemin önemli edebi kişilerinin yazdıkları yazılarda genellikle kendi imzalarını kullandıkları görülmektedir. Maarif Meclisi'nden Şinasi’nin mesai dostları ile Tercüme Bürosu'nda çalışan kimi aydınlar, Tasvîr-i Efkâr'ı yazıları ve çevirileri ile beslediler. Bu yazarlar tarafından, edebi, kültürel, tarihi gibi birçok konuda fikir yazıları kaleme alınmıştır. Gazetenin 35. sayısından itibaren yazıları çıkmaya başlayan Namık Kemal, 261. sayıdan itibaren Şinasi’nin

38 Necdet Hayta, Tarih Araştırmalarına Kaynak Olarak Tasvir-i Efkâr Gazetesi, Kültür Bakanlı̆̆ı, Ankara, 2002, s.11.

39 Tasvîr-i Efkâr'ın toplam yayın sayısı hakkında karşılaştırma için Bkz. Vedat Günyol, "Matbuat”, İslam Ansiklopedisi, c.7, İstanbul, 1979, s.368.

40 Tasvir-i Efkar'ın ilk sayısında yer alana mukaddime yazısının tamamını okumak için Bkz. Ahmet Hamdi Tanpınar, , 19. Asır Türk Edebiyatı Tarihi, 6.bs., Çağlayan Kitabevi, İstanbul, 1985, s.212.

41 Meclis-i Maarif Azası Şinasi Efendi’nin meclis azalığından ihracı ve maaşının kesilmesi hakkında Bkz. BOA, İ. DH, 510/34687 ; BOA, MKT. MHM, 268/83. 
yerine başyazarlığa terfi etmiştir. Şinasi’nin idaresinde iken, siyasi konulara doğrudan girmeyen gazete, özellikle Namık Kemal idaresinde daha sert siyasi muhalefete girişti ve Yeni Osmanlı Cemiyetinin düşüncelerinin savunucusu oldu.

\section{İçerdiği Konular Bakımından Tasvir-i Efkâr'ın Değerlendirilmesi}

Şinasi tarafından çıkarılan ve gerçek anlamda ilk önemli Türk gazetesi olarak kabul edilen Tasvîr-i Efkâr zengin bir içeriğe sahiptir. Daha önce çıkarılan Osmanlı gazetelerinin resmi, yüzeysel havasından uzak olan bu gazetede farklı olan konuların başında okuyucu köşesi gelmektedir. Daha önceki gazetelerde çok sınırlı bir biçimde yer verilen okur mektupları, sadece padişaha ve hanedana olan övgülerle ilgili idi. Oysa Şinasi, gazetesini halkın sorunlarını iletebildiği bir platforma dönüştürme gayreti içine girdi ${ }^{42}$. Gerçek okurlar, gerçek sorunları hakkında gazeteye mektuplar gönderiyor ve bunların bir kısmı yayınlanabiliyordu. Padişahın cülus ve doğum günlerinde gazetesine övgü yazıları koymamakla sivil bir gazeteciliğin önünü açıyordu.

Gazetenin içeriğine baktığımızda, resmi haberlerin çok büyük bir yer tuttuğunu söyleyemeyiz. Özellikle saray ile ilgili haberler verilirken, sade bir dil kullanılıyor, ağır övgü dolu uzun cümleler yerine, sade bir dil kullanılıyordu ${ }^{43}$. Padişahın şahsı ve sarayı eleştirilerin dışında tutuluyor, zaman zaman Tanzimat devlet adamları eleştiriliyordu. Her ne kadar resmi bir gazete olmasa da, Tasvîr-i Efkâr Gazetesinin sayfalarında askeri ve sivil yönetici atamalarına ve azillerine sıklıkla rastlamak mümkündür. Sadaret atamaları ve üst düzey atamalara yer verildiği gibi orta ve hatta alt düzeydeki memur atamalarına ait haberlere bile yer verilmiştir. Tasvîr-i Efkâr, bu tür haberleri doğrudan aldığı gibi, bazen de Takvim-i Vekâyi'deki yazılardan alıntı yapmıştır ${ }^{44}$.

Osmanlı Devletindeki ilk özel gazetelerin henüz tam olarak özel bir statüye geçmediklerini, sahiplerinin devletle olan ilişkilerini koparmadıklarını gazetelerin içeriklerinden de rahatlıkla anlamak mümkündür ${ }^{45}$. Gerek Tercüman-1 Ahvâl ve gerekse de Tasvîr-i Efkâr'da göze çarpan bir özellik, resmiyetten tam anlamı ile kopmamış olmalarıdır. İşte Tasvîr-i Efkâr' daki bu atama ve azil haberlerinin yoğunluğunun altında yatan faktör budur. Ancak yine de bu gazeteyi resmi bir gazete olarak değerlendirmek yanlıştır. Gazete bir çok yönüyle özel bir gazete niteliğini hak etmektedir.

Tasvîr-i Efkâr Gazetesinde başta İstanbul olmak üzere Osmanlı şehirlerindeki sosyal yaşamı, ekonomik durumunu, dini, kültürel, eğitim gelişmelerini gösteren birçok habere yer verilmiştir. Bu tür haberlerin başında yangınlar, Vakıflar, Asayiş, Belediye hizmetleri, Okullar, İktisadi kurumlar, Posta ve Telgraf Hizmetleri, Salgın hastalıklar gibi konularda haberler gelmektedir. Bu türden haberleri verirken, sadece başkentin durumu ile ilgili gelişmelerle sınırlı kalınmamış, memleketin birçok bölgesini, şehrini ilgilendiren olaylara yer verilmiştir.

Tasvîr-i Efkâr'da Osmanlı Devletinde yaşayan azınlıkların, diğer bir deyişle Gayr-i Müslimlerin sosyal, ekonomik, kültürel durumlarını gösteren çok sayıda haber bulunmaktadır. Sırf bu haberlerden bile yola çıkarak, bu kesimlerin sosyal, ekonomik ve hukuki açıdan büyük bir gelişme gösterdikleri anlaşılabilir. Ayrıca bunların birbirleri ile olan ilişkilerini de gösteren

42 Orhan Koloğlu, “Osmanlı Basını: İçeriği ve Rejimi”, TCTA, c.1, İletişim Yay., İstanbul, 1985, s.75.

43 Sultan Abdülaziz’in Avrupa seyahati (486-509 arasındaki sayılarda), Padişahın katıldı̆̆ı bazı törenler, saraydaki doğumlar ve ölümler hakkındaki haberler bu türdendir.

44 Örneğin, Cevdet Efendi’ye Anadolu Kazaskerliği payesi verildiğine dair Takvim-i Vekayi'den alınan haber için Bkz. Tasvîr-i Efkâr, No: 106, (3 Temmuz 1863).

45 Şerif Mardin, “Türkiye'de İletişimin Modernleşmesinin Erken Bir Safhası Üzerine Notlar”, Türk Modernleşmesi Makaleler-4, İletişim Yay., İstanbul, 1991, s.143. 
haberler yer almaktadır ${ }^{46}$. Osmanl1-Türk aydınları tarafından çıkarılan bir gazete olarak Tasvîr-i Efkâr, toplumun bu unsurları arasında yükselen ayrılıkçı, ulusçu akımlara zaman zaman dikkat çekmiştir. Bizzat Gazetenin başyazarı Namık Kemal imzasını taşıyan bir yazıda, İstanbul'daki bazı Rum gençlerinin Yunanistan'dan getirttikleri zararlı yayınları serbestçe okudukları, bunları teşhir ettikleri ve Beyoğlu'ndaki kahvelerde Türkleri aşağılayan, Rumları ise isyana teşvik eden marşlar okunduğu belirtiliyordu. Bu ayrılıkçı Rum gençliğine karş1 Zaptiye göreve çağrılıyordu ${ }^{47}$.

Osmanlı Devletinin ticari ve mali açıdan Avrupa devletlerinin denetimi altına girdiğini ve giderek bu alanlardaki bağımsızlığını kaybetmeye başladığını gösteren çok sayıda haber vardır. Ancak gazetenin yayın politikasında bu gelişmelere eleştirel bakmak durumu yoktur. Gazetenin yazarlarının ve yöneticilerinin, Osmanlı üzerindeki Avrupa ekonomik hegemonyasının ileride yol açabileceği tehlikeleri fark ettiklerine dair yorumlara rastlanmaz.

Tasvîr-i Efkâr'da Osmanlı Devletinin dış ilişkileri, yabancı devletlerin Osmanlı ile olan ilişkileri üzerinde, çok yoğun olmasa da, durulmuştur. Özellikle Osmanlı-Yunan ilişkileri, bu devletin başta Girit olmak üzere, Osmanlı coğrafyası ve toplumu üzerindeki emellerine dikkat çekilerek, işlenmiştir. Gazeteyi yönetenlerin Osmanlıcılık fikri etrafinda geliştirdikleri vatanseverlik duyguları da eklenince, bu durum ağırlık kazanmıştır.

Bunun dışında Osmanlı Devletinin Fransa ve İngiltere ile olan ilişkilerine dair birçok haber yer almıştır. Tasvîr-i Efkâr etrafında kümelenen genç Osmanlı aydınlarının bu büyük devletlerin Osmanlı politikalarına gazetede açık, belirgin bir eleştiri getirememişlerdir. Osmanlı devletini yönetenlerin bu iki devletin etkisinde olmaları, bizzat Şinasi, Namık Kemal, Ahmet Vefik gibi gazetecilerin de özellikle Fransız etkisi, hayranlığı altında bulunmaları büyük devletlerin eleştirilmesini güçleştiriyordu ${ }^{48}$. Bu iki devletin Osmanlı bütünlüğünü koruyormuş gibi görünmeleri de bu tutumda etkili olabilir. Tasvîr-i Efkâr, Osmanlının Rusya, Avusturya, İtalya, İran, Amerika gibi birçok ülke ile olan ilişkilerine de zaman zaman yer vermekte idi.

Yabancı ülkelerde yaşanan olaylar, bu ülkelerin özellikleri, kurumları, kültürleri gibi konular da Tasvîr-i Efkâr'da yer bulmakta idi. Hatta şaşırtıcı bir biçimde bu türden haberler, Osmanlı Devletinin dış ilişkilerinden daha fazla yer kaplıyordu. Osmanlı aydının dünya algısını ortaya koyan bu tür haberler, aynı zamanda halkın dış dünyayı tanımasına hizmet ediyordu. Yabancı ülkeler ile ilgili ve büyük çoğunlukla yabancı gazetelerden alınan haberler konu bakımından çok çeşitlilik gösteriyordu. Yani dışarıda yaşanan her türlü resmi ve özel olaylara yer verilebiliyordu. İngiltere'de parlamentonun toplanması, İngiliz kraliyet ailesi ile ilgili haberler, Fransız İmparatoru ve Fransa'daki Millet Meclisi Faaliyetleri, İtalya'daki ulusal uyanış ve İtalyan mücadeleleri, Avusturya'nın Prusya ve İtalya ile olan muharebeleri gibi çeşitli önemli konulara yer veriliyordu.

Tasvîr-i Efkâr Gazetesinin içerdiği konulara bakıldığında, eğitim ve edebiyat konularına çok önem verildiği ortaya çıkar. Başta Şinasi ve Namık Kemal olmak üzere, gazetenin yayın politikasını belirleyen kişiler sadece gazeteci değildirler. Onlar aynı zamanda birer şair, dilbilimci, yazardırlar. Gazete, eğitim ve hayır işleri ile ilgili her türlü ilanı ücretsiz basmıştır. Osmanlı Devletinde açılan modern okullar ve bu okullarda verilen eğitim Tasvîr-i Efkâr tarafından sıkı bir

46 Örneğin, İzmir'de Rumlarla Yahudiler arasında çıkan çatışmalar o kadar büyümüştü ki, devlet İstanbul'dan buraya özel bir heyet göndermiş ve çatışmalar güçlükle durdurulabilmişti. İlgili haber için Bkz. Tasvîr-i Efkâr, No: 77, 94, (22 Mart ve 21 Mayıs 1863).

47 Bkz. Tasvîr-i Efkâr, No: 419, (17 Eylül 1866).

48 Yabancı bir gazeteye dayanarak, Rusya'nın Osmanlı içindeki azınlıkları kıkırtıcı rolünden bahseden Tasvir-i Efkâr, İngiltere ve Fransa'nın Osmanlı aleyhindeki faaliyetlerini hiç bahis konusu yapmamıştır. Bkz. Tasvîr-i Efkâr, No: 674, ( 21 Eylül 1868). 
biçimde takip edilmiş ve bunlarla ilgili çok sayıda yazı yazılmıştır. Bir eğitim dili olarak Türkçenin geliştirilmesi savunulmuştur ${ }^{49}$.

Türk ve Müslüman halkın eğitimde diğer toplum unsurlarından geri kaldığının farkında olan ve eğitim seviyesinin yükseltilmesi, eğitimin yaygınlaştırılması gerektiğinden hareketle Tasvîr-i Efkâr, bu tür konulara ağırlık vermiştir. Örneğin, bir tür halk eğitimi kuruluşu olarak ortaya çıkan Cemiyet-i Tedrisiyye-i Íslamiyye' ye geniş bir yer ayırmış ve birçok sayısında bu kuruluşu tanıtmıştır ${ }^{50}$. Bunun dişında gerek başkentte ve gerekse de taşrada faaliyet gösteren devlet okulları ile ilgili haberlere sütunlarında önemli oranda yer verilmiştir.

Bir politika ya da havadis gazetesi olmaktan daha çok kültür-sanat ağırlıklı bir gazete olan Tasvîr-i Efkâr, kültürel, sanatsal gelişmelere, kitap dünyasına özel bir değer vermekte idi. Piyasaya çıkan özellikle Türkçe kitapları tanıtan, haber yapan gazete, dönemin kültürel hareketliliğini yansitmaktadır. Aynı zamanda özel bir matbaaya sahip olan gazete, matbaasında basılan kitapları da öncellikle duyurmakta idi ${ }^{51}$.

Osmanlı Gazeteleri içerisinde tefrika çalışmalarına en fazla yer veren gazetelerin başında Tasvîr-i Efkâr gelmektedir. Bu bölümde, değişik konularla ilgili yazılmış olan kitaplar bölümler halinde okuyucuya sunulmaktadır. Günümüzdeki anlamıyla gazete eki diyebileceğimiz ve özel bir başlık altında verilen onlarca tefrika çalışması vardır. Bunlardan bazıları şunlardır: Ahmet Vefik: Hikmet-i Tarih, Buffon: Tarih-i Tibb, Hukuk-i Milel, Carlonis Ciovannis: Avrupa Tarihi, Vattek: Hukuk-i Nas ve Hükümdarân, Salih Efendi: Tarih-i Tabii, Katip Çelebi: Düsturul Amel, Mizanul Hakk .......

Oldukça önem verilen bu tefrika çalışmalarından bazılarının yine de çeşitli nedenlerle yarım bırakıldığ 1 görülmektedir. Gazetedeki haberlerden anlaşıldığına göre dönemin en önemli kültür kurumlarından biri de kıraathanelerdir. Özellikle başkent İstanbul'da sayıları her geçen gün artan kıraathaneler, aynı zamanda gazetelerin ve kitapların bulunduğu mekanlar olarak bu konuda adeta birbirleri ile yarışmaktadırlar. Kıraathanelerle ilgili çok sayıda habere yer veren Tasvîr-i Efkâr, insanları bu kurumlara yönetme çabası içindedir ${ }^{52}$.

Tasvir-i Efkâr' da dönemin basın hayatı ile ilgili gelişmelere de yer verilmiştir. İstanbul'da çıkan gazetelerin durumu ve özellikle vilayetlerde çıkmaya başlayan yerel gazeteler ile ilgili gelişmeler ve bu gazetelere dayanılarak verilen haberler önemli oranda yer tutmaktadır. Basın tarihimizde gazeteler arasındaki polemikler, edebi ve siyasi tartışmalar, Tasvîr-i Efkâr'ın çıkması ile belirli bir seviyeye gelmiştir ${ }^{53}$.

49 Gazete, Tıp derslerinin Fransızca okutulmasını eleştiriyor, derslerin Türkçeye çevrilmesi gerektiğini ve bunun için bir çeviri komisyonunun kurulması gerektiğini savunuyordu. Bkz. Tasvîr-i Efkâr, No: 437-438, (20-24 Kasim 1866).

50 Bu dernekle ilgili bazı haberler için Bkz. Tasvîr-i Efkâr, No: 189, 280, 285, 319, 362, 365, $400,476$.

51 Yazdığı ve tercüme ettiği birçok eserle Çağdaş Türk Edebiyatında önemli bir yeri olan Şinasi, gazetesinin 113. sayısında, Türk Atasözlerini derleyen Durûb-1 Emsâl-i Osmaniye adlı kitabını bastırdığını okuyucularına duyuruyordu. Bkz. Tasvîr-i Efkâr, No: 113, (27 Temmuz 1863).

52 Direklerarası'nda 63 no'lu kıraathanenin sahibi olan Mehmet Efendi'nin İstanbul'da yayınlanan bütün gazeteleri ve taşrada çıkan gazeteleri bulundurduğu ve ayrıca kıraathanesinde her çeşit nefis kitabı okuyucuları için bulundurduğuna dair ilan için Bkz. Tasvîr-i Efkâr, No: 522, (1 Ekim 1867)

53 Titiz, bilgili ve birikimli bir edebiyatçı olan Şinasi’nin özellikle Ruznâme-i Havâdis-i Ceride'de yazan Ayan Reisi Sait ile giriştiği dil, grammer tartışması, Türk Edebiyat Tarihinin ilk önemli tartışması olmakla meşhurdur. Edebiyat tarihinde "Mebhusetu anha" olarak da bilinen bu münakaşa için Bkz. Tasvîr-i Efkâr, No: 362, (30 Ocak 1865) ; Şinasi’nin münakaşa kabiliyetini, mantıktaki kudretini ve dil bilgisini takdir edererk, onun Türkçe'deki yabancı sözcükleri azaltmak istediğine dair görüş için 
Sonuç olarak, işlediği konular itibarı ile bakıldığında, Tasvîr-i Efkâr'ın bütüncül bir gazete olarak her türlü siyasi, sosyal, iktisadi ve kültürel konuları işlediğini görülür. Bu türden konuların belirli bir sabit oranlı ağırlıkları oldukları söylenemese de, özellikle kültür ve eğitim konularının ilk kez bir Türk gazetesinde bu denli önem kazandığı dikkat çekmektedir. Bu konular sadece somut birer haber olarak verilmemiş, haberlere zaman zaman yorumlar da eklenmiştir.

\section{Türk Basın Tarihinde Tasvir-i Efkâr'ın Önemi}

Tasvîr-i Efkâr'ın Türk Basın Tarihinde çok önemli bir yeri olduğu konusunda hemen hemen bütün araştırmacılar hem fikirdir ${ }^{54}$. Onu tarihimizde önemli kılan özelliklerin başında, ilk özel Türkçe gazetelerden biri olması gelmektedir. Tercüman-1 Ahvâl'den sonra çıkarılan ikinci özel Türkçe gazetedir. Bu gazeteyi daha da önemli kılan özelliklerden biri ise, fikir gazeteciliğimizin öncüsü olmaktan doğmaktadır. Ciddi anlamda bir düşünce gazetesi olarak, fikir gazeteciliğinde bir çı̆̆ır açmıştır.

Döneminin tertip, düzen ve teknik bakımından oldukça ileri düzeyde bir gazete olan Tasvîr-i Efkâr, kendisinden yıllar sonra çıkan birçok Osmanlı gazetesinden bile daha gelişmiş̧tir ${ }^{55}$. Kendi özel matbaasında basılan bu gazete, yayınını yıllarca, düzenli bir biçimde sürdürmüş ve bine yakın sayı çıkarmıştır. Rakipleri olan Osmanlı gazetelerine oranla uzun sayılabilecek bir sürede ayakta kalabilmesi ve periyodik yayınına uymaya dikkat etmesi önemlidir.

Tasvir-i Efkâr, Osmanlı basın hayatına bir canlılık, hareketlilik ve rekabet ortamı getirdi. $\mathrm{Bu}$ kadar düzenli ve gelişmiş bir rakip karşısında ayakta kalma savaşı veren diğer gazeteler daha düzenli çıkma gayreti içine girdiler. Bu rekabet etme hevesi özellikle Ceride-i Havâdis'te belirgin biçimde görüldü. 1840 y1lından beri William Churchill ve daha sonra oğlu Alfred Churchill tarafindan çıkarılmakta olan bu yarı resmi gazete, özel Türkçe gazetelerin çıkması ile, 1864 yılında Ruznâme-i Ceride-i Havâdis adını alarak etkin olmaya çalıştı ise de, Tasvîr-i Efkar'la rekabet edemedi $^{56} .25$ Mayis 1865 'te bu gazete kapand1.

Tasvîr-i Efkâr Gazetesi, daha önce hiçbir Osmanlı gazetesinin keşfedemediği bir şeyi, kamuoyunu keşfetmiştir. Şinasi, gazetesinin amacını, halka inmek ve halka, kendi yararlarını düşünmek ve sorunları üzerinde durmayı öğretmek olarak açıklıyordu. Böylece kamuoyunun önemini vurgulamakta idi ${ }^{57}$. Zaten bir özel gazete olarak, devlet hazinesinden beslenmeyen Tasvîr-i Efkâr, halka dayanmak zorunda idi. Müslüman Türk halkının düşüncelerini, duygularını bir bakıma temsil eden bir gazete olarak halktan yoğun bir ilgi gördü. Dönemin Türkçe gazeteleri arasında en çok satan gazete oldu. Tasvîr-i Efkâr'ın bir dönem yirmi dört bin sattığı rivayet edilmiştir. Bu sayı tam olarak gerçek olmasa da, Şinasi'nin gazetesinin önemli oranda rağbet gördüğü bir gerçektir ${ }^{58}$.

Bkz.Tanpinar, a.g.e., s. 214

54 Ertuğ, a.g.e., s.170; İnuğur, a.g.e., s. 195 ; Şapolyo, a.g.e., s.117, ;Oral, a.g.e., c.1, s. 80 ; Akün, a.g.m., s. 550 .

55 Dönemin sadrazamı olan Fuat Paşa tarafından çok beğenilen gazete, Padişaha takdim edilmiş ve gazeteyi beğenen padişah, yaveri aracılığıyla Şinasi Efendi'ye beş yüz altın ihsanda bulunmuşsa da, Şinasi bu yardımı kabul etmeyerek, geri göndermiştir. Bkz. İnuğur, a.g.e., 196.

56 Mustafa Nihat, "Yüzyıllık Gazeteciliğimiz", Ayın Tarihi, S.46-47, Ankara, 1928, s.2955.

57 Koloğlu, a.g.m., s.78.

58 1860'larda Osmanlı'da bir gazetenin günlük yirmi bin civarında satış yapması inanılmaz bir rakam gibi görünmektedir. Oysa aynı yıllarda Avrupa'da gazetecilik Osmanlı ile kıyaslanamayacak ölçüde yaygınlık kazanmıştır. Örneğin, İngiltere'de Daily Telegraph Gazetesinin günlük satış rakamı iki yüz bin civarında idi. Aynı yıllarda Fransa'da sadece başkent Paris’te gazetelerin günlük ortalama satış 
Tasvîr-i Efkâr, daha önce örneklerine rastlanmayacak ölçüde okuyucu mektuplarına yer vermekle Türk Basın Tarihine önemli bir yenilik getirmiş oluyordu. İkinci önemli yenilik ise, Şinasi'nin Arap harfleri ile dizgiyi kolaylaştırmak için dizgi kasasındaki harf sayısını azaltması idi. Sadeliğe, halkın rahatça okumasına ve anlamasına büyük bir önem veren Şinasi, Müteferrika'dan beri matbaacılıkta kullanılan 500'den çok harf kasasını 112'ye indirerek, daha okunaklı bir yazı oluşturma yoluna gitti. Böylece tarihimizde bu dönemlerden itibaren başlayan dil çağdaşlaşması, harf sorunu konusunda Şinasi'nin ve gazetesinin önemli bir katkısı oluyordu ${ }^{59}$.

Okurunu eğitmek, onun bilgi ve bilinç dünyasını genişletmek amacını en açık biçimde taşıyan gazetelerin başında gelen Tasvîr-i Efkâr, tefrika çalışmalarını biraz da bu amaçla yayınlıyordu. Tarihe, Hukuka, Doğaya, Felsefeye, Kamu yönetimine ve diğer birçok alana bilimsel yaklaşan yerli ve yabancı eserler ilaveler biçiminde gazetede yayımlandı. Bu sayede bir halk aydınlanmasına hizmet edildiği düşüncesi hâkimdi. Burada, seyrek de olsa, yayımlanan bazı tefrikalarda ilk kez Osmanlının dışında bir Türk kimliğinden ve tarihinden bahsedenlere de rastlamak mümkündü. Ebul Gazi Bahadır tarafından yazılan "Evsâl-i Şecere-i Türki” adındaki eserin yayınlanması, genel bir Türk Tarihi ve kültürü açısından önemli idi ${ }^{60}$.

Tasvîr-i Efkâr, Türkçe Osmanlı gazeteleri arasında devlet karşısında bağımsız durmaya en çok önem veren gazetelerin başında gelir. Basının tarafsızlığı, bağımsızlığı gibi ilkelere önem veren ve bunu ifade hürriyeti için gerekli gören Şinasi, hazine ve saray yardımları almamakla serbest duruşunu muhafaza etmek istedi. Şinasi'nin yurtdışına çıkmasından sonra gazeteyi yönetmeye başlayan Namık Kemal, yönetime karşı olan muhalif duruşunu göstermeye başladı. Bu bakımdan Tasvîr-i Efkâr, ilk önemli muhalif Osmanlı gazetesi sayılabilir. Genç Osmanlı aydınlarının üzerinde etki birakan ve onlardan etkilenen bir gazetedir ${ }^{61}$.

1865 yılına kadar muhalefetini oldukça ihtiyatlı ve sınırlı bir biçimde sürdürebilen ve daha çok çeviriler ve dil konuları üzerinde yoğunlaşan Tasvîr-i Efkâr, bu tarihten itibaren giderek muhalif duruşunu geliştirdi. İlk olarak kentin sorunları (Hastalıklar, yangınlar) hakkında yöneticiler eleştirilmeye başlandı. Eleştiriler giderek, hükümetin eğitim ve maliye gibi alanlardaki politikalarındaki yanlışlıklarının ortaya konması ile geliştirildi. Hükümete yönelik eleştirilerin giderek, siyasi alana kaydığını ve Yeni Osmanlıların ideolojik muhalefetine dönüştüğünü görmek mümkündür.

1867 yılında Mustafa Fazıl Paşa'nın padişaha yazdı̆̆ı açık mektubu yayınlayan gazetelerden biri de Tasvîr-i Efkârd1. Osmanlı'da adeta birer siyasi parti gibi muhalefet eden basınla mücadele etmek için hükümet, daha sert tutum takındı. Namık Kemal'in gazetenin 10 Mart 1867 tarihli 465. sayısında yayınladığı "Şark Meselesi”nden sadece beş gün sonra Sadrazam Âlî Paşa, "zararlı basını" susturmak için Kararnâme-i Ali denilen ünlü yasakları getirdi ${ }^{62}$. Buna göre, gazeteler gerektiğinde, basın yasasından ayrı olarak hükümetin vereceği idari bir yetkiyle kovuşturmaya uğrayacaktı. Burada önemli bir nokta şudur: Osmanlıda faaliyet gösteren yabancı basın her türlü serbestliğe sahipken ve hükümet bunlara hiçbir surette karışamazken, başta Tasvîr-i Efkâr olmak üzere Türkçe basın hükümet tarafından sıkı denetim altına alınmak istenmektedir.

rakamları bir milyonu geçiyordu. Bkz. İnuğur, a.g.e., s.124.

59 Niyazi Berkes, Türkiye’de Çă̆daşlaşma, 7.bs., Yapı Kredi Yayınlar, İstanbul, 2004, s. 265.

60 Tasvir-i Efkâr, No:131-173,(28 Eylül 1863- 25 Şubat 1864).

61 Ebuziya’nın deyimiyle: "Tasvîr-i Efkâr, yeni fikirli gençlerin buluşma yeri idi.” Bkz. Ebuziya TEVFİK,"Yeni Osmanlılar", Yeni Tasvîr-i Efkâr, No: 10, ( 10 Haziran 1909).

62 Bu dönemdeki Türkçe gazetelerin idarehânesini birer siyasi kulübe, gazeteleri de birer halk kürsüsne benzeten görüşleri için Bkz. Enver Ziya Karal, Osmanlı Tarihi, VII. Cilt, 3. bs., T.T.K. Basımevi, Ankara, 1983, s. 301. 
Osmanlı'nın çağdaşlaşmasını savunan Tasvîr-i Efkâr, kadınların okutulması ve toplum hayatında yer almasını savunan yazılara da yer verdi. Namık Kemal, Terbiye-i Nisvâna Dair kaleme aldığı makalesinde kadınların beşeri kabiliyetlerinin inkişaf ettirilmesi gerektiğini vurguluyordu ${ }^{63}$. Ayrıca şehrin sosyal ve kültürel hayatının edebiyata ve gazeteye aktarılması, Tasvîr-i Efkâr'ın kültür tarihimizdeki önemini artırıyordu. Gazetenin 452. sayısından 455. sayısına kadar bir dizi halinde yayınlanan Ramazan Mektupları Müslüman İstanbul halkının dini ve sosyal yaşantısına 1 ş1k tutuyordu.

Tasvîr-i Efkar'ın kültür tarihimizdeki asıl önemi, Türk dilinin gelişmesi için önemli katkılarda bulunmasıdır. Gazetenin sahibi olan Şinasi'ye göre halka yönelen bir gazetenin halk tarafından anlaşılabilmesi için sade, anlaşılabilir bir dili kullanmak gerekmekte idi. Dilin sadeleşmesi ak1mında gazete bir aracı rol oynadı. Gazetede kullanılan cümlelerin kurallı ve düzgün ifadelerden oluşmasına gayret edildi. Noktalama ve imla işaretleri Türkçede ilk kez bu denli titizlikle kullanılıyordu. Zaten bu gazeteye emek veren Şinasi, Ahmet Vefik, Recaizade Ekrem gibi kişilerin önemli dilbilimciler olmaları, edebi eserler kaleme almaları, hatta sözlük çalışmaları yapmaları onu edebiyat tarihimizde, belki de başka hiçbir gazetenin olmadığı kadar önemli kılıyordu.

Türk dilinin ve edebiyatının sorunlarını derinlemesine, toplu biçimde ele alan ilk makaleler, bir dizi halinde Namık Kemal tarafindan Tasvîr-i Efkâr Gazetesinde yayınland1. "Lisân- $\iota$ Osmanînin Edebiyatı Hakkında Mülâhazâtı Şamildir" başlı̆̆ı ile yayınlanan bu makale dizisinde, devletin resmi dilinin, halkın konuştuğu dilden uzak olmasına dikkat çekiliyor, resmi dilin sadeleştirilmesinin önemine değiniliyordu ${ }^{64}$.

\section{Sonuç}

Türk Basın Tarihinin gerçek anlamda ortaya çıkması ancak XIX. Yüzyılın ikinci yarısında gerçekleşmiştir. Oysa Avrupa Tarihine baktığımızda basın hayatının XVII. Yüzyıl ortalarından itibaren başladığını ve XVIII. Yüzyılda iyice geliştiğini görmekteyiz. Osmanlılar, Matbaa konusunda çok geciktikleri gibi Gazete çıkarma konusunda da gecikmişlerdir. Gerek matbaa ve gerekse de gazete konusunda Osmanlıda yaşayan azınlıklar ve yabancılar öncü olmuş; Türkler ise, bu yeniliklerle çok daha sonra tanışmışlardır.

Osmanlıda devletin basının önemini kavraması, Batılılaşma politikasının başlaması ile parelilik göstermekte ve basın, devletin ıslahatlarını halka anlatan resmi bir araç olarak görülmektedir. Ancak Tanzimat Dönemi ile birlikte Türkçe gazete çıkarması için yabancı uyruklu kişiler devlet tarafından teşvik edilip, kendilerine hazine yardımı yapılırken, Müslüman-Türk halkın bu konuda hiç teşvik görmemesi Tanzimat zihniyetini göstermesi bakımından düşündürücüdür.

1831 yılında devletin tekeli altında başlayan Türkçe basının, Müslüman Tük halkına mal olması için otuz yılın daha geçmesi gerekmiş ve nihayet 1860 yılında ilk kez Türkçe basın konusuna Türkler el atmışlardır. Aynı zamanda birer devlet memuru olan genç Türk aydınları, basının önemini kavramaya başlamış ve gazete çıkarmak için devletten izin almışlardır. Agah Efendi, devletin dışında, bir gazeteye sahip olan ilk Türk olarak 1860 yılı sonlarında Tercüman-1 Ahvâl Gazetesini çıkarmıştır.

Türk Basın Tarihinde en önemli yere sahip olan öncü kişi İbrahim Şinasi'dir. Özel Türkçe basının yayın hayatına başlaması önemli ölçüde onun eseridir. Gazeteyi sadece haber aracı değil;

63 Tasvir-i Efkâr, No: 457, (26 Kanunusani 1283).

64 Tasvir-i Efkâr, No: 416-417, (16-19 Rebiülahir 1283). 
aynı zamanda edebiyat, sanat, yorum, bilim gibi konularda da bir araç olarak görmüş ve fikir gazeteciliğinde çığır açmıştır. Tercüman-ı Ahvâl'de yayınladığı imzalı giriş yazısında çok önemli mesajlar vermiş ve çağdaş bir dünya görüşü ortaya koymuştur. Ona göre, gazete halkın anlayacağ 1 sade bir dille yayın yapmalı, sütunlarında halkın görüşlerine yer vermelidir. Devletle ilgili konularda söz söyleme hakkı bulunan, sorumlu vatandaşın gerekli olduğunu belirten Şinasi, bir Müslüman -Türk devleti olan Osmanlı' da Müslüman halkın diğer unsurların gerisinde kaldığına dikkat çekiyordu. Gazete, halkın kültürel seviyesini artıran, halkı eğiten bir araçtır.

Gazetenin kamuoyu oluşturmadaki gücünü fark eden Şinasi, kendi özel gazetesi olan Tasvîr-i Efkâr'1 1862 yılında çıkard1. Türk basın tarihinde çok önemli bir yeri olan bu gazete, nitelik, biçim ve içerik yönünden Tanzimat Döneminin en gelişmiş Türk gazetesidir. Özel gazete niteliğini daha çok karşılayan, devlet yönetimine karşı zaman zaman muhalif bir duruş sergileyen Tasvîr-i Efkâr, kendi özel matbaası bulunan düzgün bir gazetedir. Özellikle Türk dili ve edebiyatının gelişmesinde, sadeleşmesinde ve halka inmesinde önemli bir araç olmuştur. Bütün bunların sonucunda daha önceki ve kendi zamanındaki Türkçe gazetelerin içinde en fazla ilgi gören gazetesidir. Ancak yine de gazete henüz okuma-yazma seviyesi çok düşük olan halka tam anlamı ile inememiş ve hükümetin de yasaklayıcı politikaları sonucu uzun süre yaşayamamıştır.

\section{KAYNAKÇA}

1. Tasvir-i Efkâr Gazetesi'nin Hakkı Tarık Us Koleksiyonu ve Atatürk Kitaplığındaki Sayıları

2. Arşiv Vesikaları

A. MKT. MHM, 268/83, 377/68

A. MKT.MVL, $127 / 91$.

İ.DH., 510/34687.

İ.MVL, 448/19983.

\section{Kitaplar ve Makaleler}

Akün, Ömer Faruk, “Şinasi”, İslam Ansiklopedisi, c.11, İstanbul, 1979.

------ ------ "Namık Kemal”, İslam Ansiklopedisi, c.9, İstanbul, 1979.

Akyüz, Kenan, “Şinasi’nin Fransa' daki Öğrenimi ile İlgili Belgeler”, Türk Dili, No: 31, 1954.

Banarlı, Nihad Sami, Resimli Türk Edebiyatı Tarihi, M.E.B. Yay., İstanbul, 1978.

Berkes,Niyazi, Türkiye'de Çăgdaşlaşma, 7.bs., Yapı Kredi Yayınlar, İstanbul, 2004.

Cevad, Mahmut, Maârif-i Umûmiye Nezareti Tarihçe-i Teşkilat ve Ícraatı, M.E.B. Yay., Ankara, 2002.

Cevdet, Paşa, Tezâkir, Yay. Cavid Baysun, T.T.K. Basımevi, Ankara, 1991.

Dizdaroğlu, Hikmet, Şinasi: Hayatı ve Eserleri, İstanbul, 1954.

Duman, Hasan, Osmanl - Türk Süreli Yayınları ve Gazeteleri (1828-1928), 3 cilt, Enformasyon ve Dokümantasyon Hizmetleri Vakfi Yay., Ankara, 2000.

Ekinci, Necdet, “Türk Basın Tarihinden Kesitler”, Türkler Ansiklopedisi, 
Ersoy, Osman, “Türkiye’ye Matbaanın Girişi ve ilk Basılan Eserler”, AÜDTCF, Yay., Ankara 1959.

Ertuğ, Hasan Refik, Basın ve Yayın Hareketleri Tarihi, c.1, İstanbul, 1959.

Gerçek, Selim Nüzhet, Türk Gazeteciliği, İstanbul, 1931.

Giz, Adnan, “İlk Türk Gazetesinin Adı Nasıl Seçildi?”, Belgelerle Türk Tarihi Dergisi, S.64, 1973.

Gövsa, İbrahim, Alaaddin, Türk Meşhurları, Yedigün Neşriyatı, İstanbul.

Günyol, Vedat, "Matbuat”, Íslam Ansiklopedisi, c.7, İstanbul, 1979.

Hayta, Necdet, Tarih Araştırmalarına Kaynak Olarak Tasvir-i Efkâr Gazetesi, Kültür Bakanlığı, Ankara, 2002.

------ ------- , Türk Basınında İz Bırakanlar, İstanbul, 1988.

İnal, Mahmut Kemal, Son Asır Türk Şairleri, Milli Eğitim Basımevi, c.10, İstanbul, 1940.

------ ------, Son Sadrazamlar, Milli Eğitim Basımevi, İstanbul, 19

İnuğur,M. Nuri, Basın ve Yayın Tarihi, Der Yayınları, İstanbul, 1993.

İskit, Server, Amme Efkârı ve İlk Gazetelerimiz, İstanbul, 1959.

------ -------, Türkiye 'de Matbuat İdareleri ve Politikaları, Başvekalet Basın ve Yayın Umum Müdürlüğü Yay., Ankara, 1943.

Basımevi, Ankara, 2000.

Ankara, 1937.

Karal, Enver Ziya, Osmanlı Tarihi, 3.bs., c.7, T.T.K. Basımevi, Ankara, 1983.

Kurdakul, Necdet, Tanzimat Dönemi Basınında Sosyo-Ekonomik Fikir Hareketleri, Ankara, 1997.

Koloğlu, Orhan, “Osmanlı Basını: İçeriği ve Rejimi”, Tanzimattan Cumhuriyete Türkiye Ansiklopedisi, c.1, İletişim Yay., İstanbul, 1985.

Yay., İstanbul, 1987.

1988.

----- ------ "İlk Türkçe Gazete; Vakayi-i Mısriye”, Tarih ve Toplum Dergisi, c.58, Ekim

Lewis, Bernard, Modern Türkiye'nin Doğuşu, çev.Metin Kıratlı, 8.bs., T.T.K. Yay., Ankara, 2000 .

Lutfi, Efendi, Vakanivüs Ahmed Lutfi Efendi Tarihi, Haz. Münir Aktepe, c.11,12,13, T.T.K. Yay., Ankara, 1988.

Mustafa, Nihat, "Yüz yıllık Gazeteciliğimiz", Ayın Tarihi, S.46-50, Matbuat Müdüriyet-i Umumiyesi, Ankara, 1928.

Münif “ Zuhûr-i Tasvir-i Efkâr”, Mecmûa-i Fünûn, S.1, Muharrem 1279.

Oral, Fuat Süreyya, Türk Basın Tarihi, Yeni Adım Matbaası. 

1990.

Ortaylı, İlber, “Tanzimat Devri Basını Üzerine Notlar”, Cahit Talas'a Armă̆an, Ankara,

Özön, Mustafa Nihat, “Yüzyıllık Gazeteciliğimiz”, Ayın Tarihi, S.46-47, Ankara, 1928.

Parmaksızoğlu, Abbas, Türk Gazetecilik Tarihi ve Basın Tarihi, 2 cilt, İstanbul, 1983.

Rasim, Ahmet, Ilk Büyük Muharrirlerden Şinasi, Yeni Matbaa, İstanbul, 1927.

Refik, Ahmet, “Şinasi’nin Berâ-yı Tahsil Paris’e Gitmesi”, T.T.E.M., No: 9, Ankara, 1925.

Sümer, Tülin, “'̇lk Büyük Gazetecimiz Şinasi ve Tasvir-i Efkârın Çıkışı”, Belgelerle Türk Tarihi Dergisi, S.26, İstanbul, 1969.

Şapolyo, Enver Behnan, Türk Gazetecilik Tarihi ve Her Yönüyle Basın, Güven Matbaas1, Ankara, 1969.

Tanpınar, Ahmet Hamdi, 19. Asır Türk Edebiyatı Tarihi, 6.bs., Çağlayan Kitabevi, İstanbul, 1985.

Tevfik, Ebuziyya, “Yeni Osmanlılar”, Yeni Tasvîr-i Efkâr, No: 10-12, 1909.

Topuz, Hıfzı, 100 Soruda Türk Basın Tarihi, İstanbul, 1973.

Yazıcı, Nesim, “Tanzimat Dönemi Basını”, Tanzimatın 150. Yılı Uluslararası Sempozyumu, Ankara, 1989.

------ ------ , Takvim-i Vekâyi: Belgeler, G.Ü.B.Y.Y.O. Yay., Ankara, 1983.

------ ------- , “Takvim-i Vekayi ve Ceride-i Havadis'in Mukadimmelerinin Karşılaştırılması", G.Ü. B.Y.Y.O. Dergisi, S.6,Ankara, 1984.

Yöntem, Ali Canip, Türk Edebiyatı Antolojisi, İstanbul, 1934.

Ziyad, Ebüziya, Şinasi, Haz. Hüseyin Çelik, İletişim Yay., İstanbul, 1997. 


\section{EKLER}

Ek-1: İbrahim Şinasi Efendi (Kaynak: Tanzimat I, Maarif Matbaası, İstanbul, 1940.

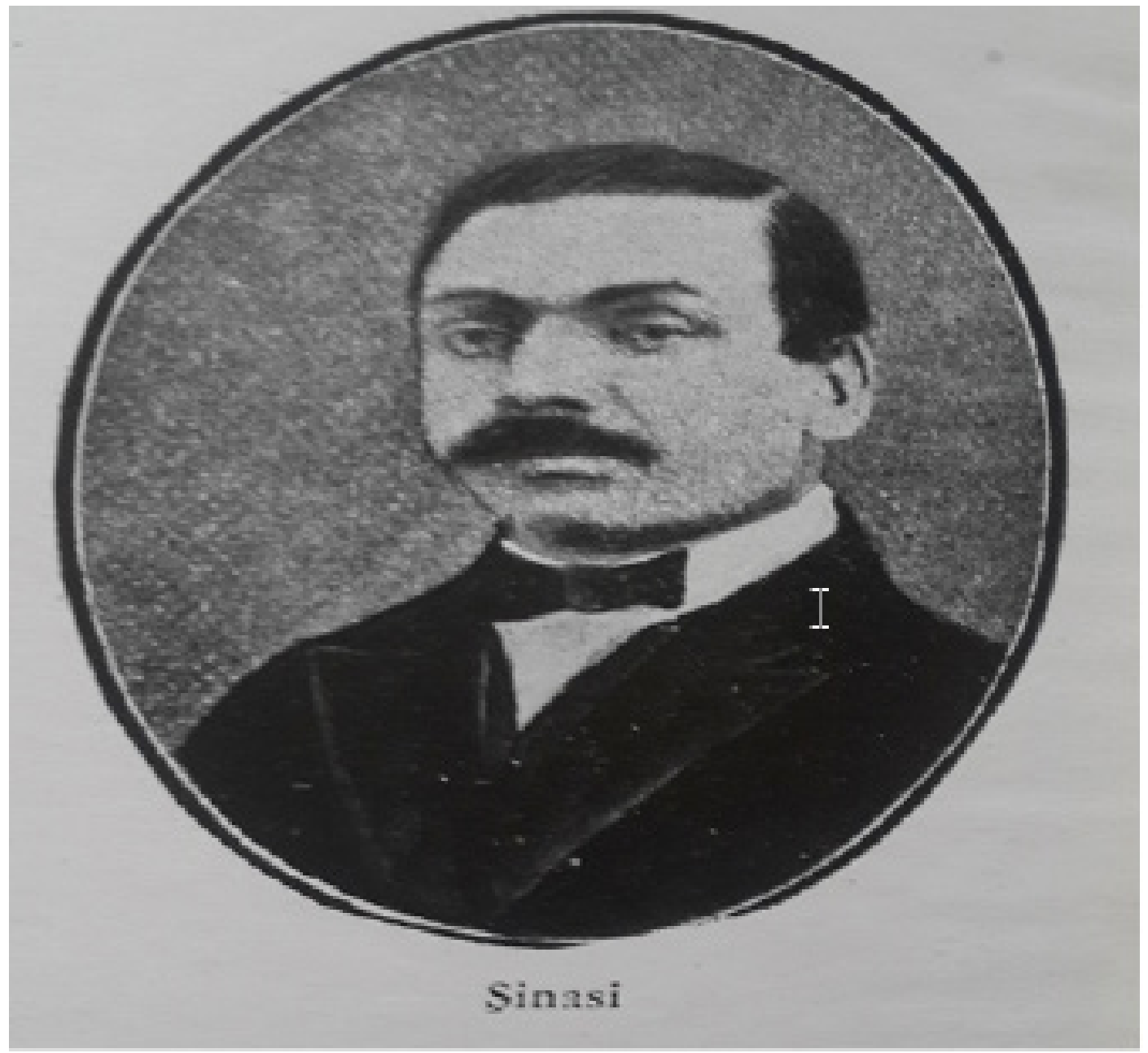


Ek-2: Tasvir-i Efkâr Gazetesi'nin İlk Sayısı (Miladî 27 Haziran 1862: Rumî 15 Haziran 1278)

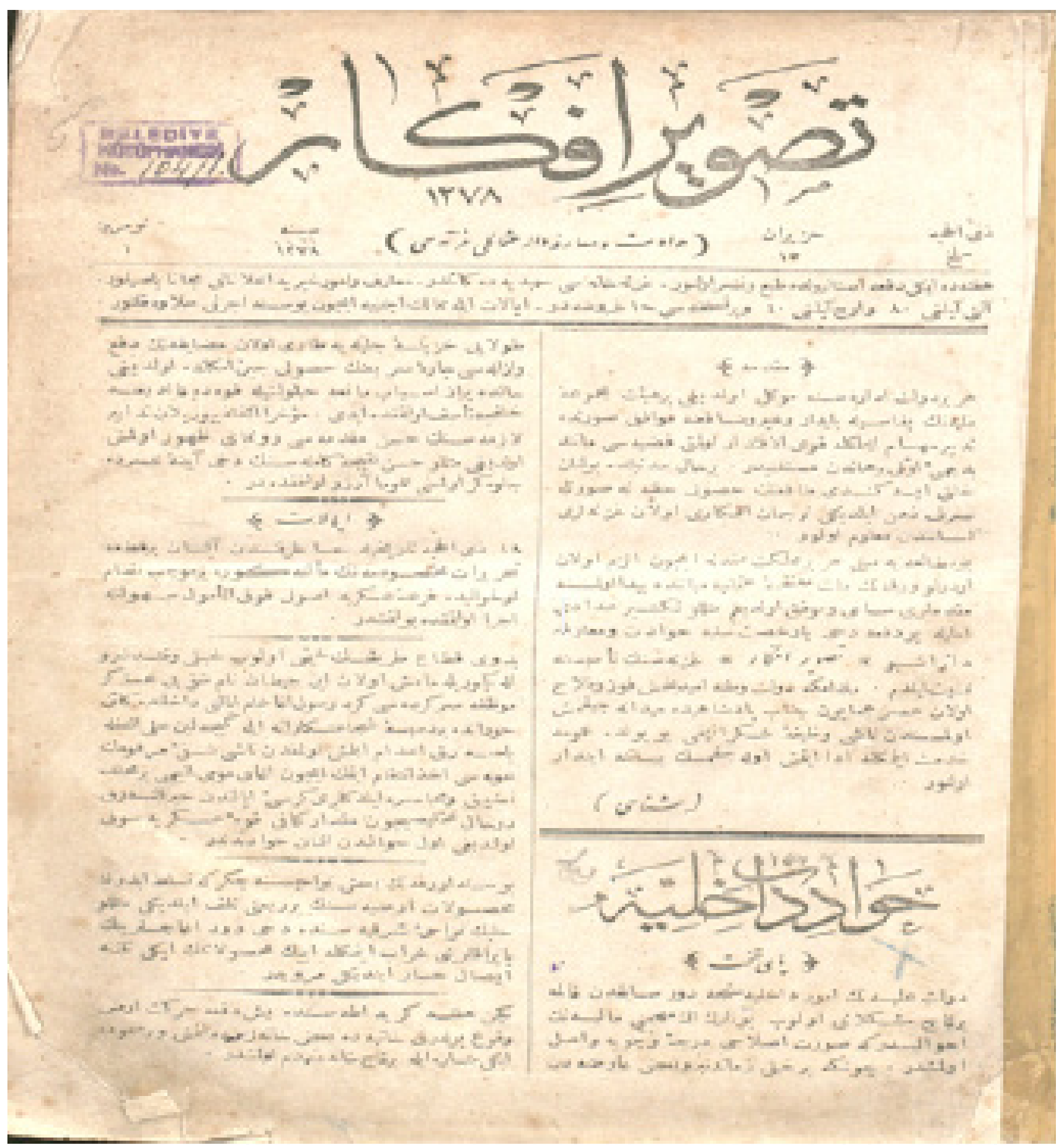

